\title{
The Prophet in a Muslim Age of Revolutions (ca. $1775^{-185^{\circ}}$ )
}

\author{
Stefan Reichmuth
}

The period between 1775 and 1850 holds its place in European and American historical consciousness as a time of far-reaching transformations and revolutions that initiated a definite break with the conventional frames of political, religious, and cultural legitimacy. At the same time, this period is connected with the economic and imperial expansion that was to establish European rule over large parts of the world in the course of the nineteenth century.

Whereas this Euro-American "Age of Revolutions"1 with its political and industrial dimensions continues to be discussed for its lasting heritage and its global repercussions, a striking series of Islamic reformist and revolutionary movements can be found in the same period. Sometimes they originated from the activities of prominent Islamic scholars and Sufi brotherhoods, or emerged in response to growing dissatisfaction with local and regional holders of power. Not infrequently this led to the foundation of new dynasties or even to novel forms of statehood. Examples have been documented for many parts of the Muslim world, in regions as distant as West Africa, South East Asia, and China. What will be presented here is a short overview and exploration of the scholars, brotherhoods, movements, and newly founded states involved in that process. We will indicate the different regional contexts within which they were located, and also the commonalities and connections which they shared despite their far-reaching distances from each other. Many of the early movements were first committed to local religious and sociopolitical changes and transformations before being drawn into the confrontation with European or Chinese imperial expansion. Others were directed from the start against foreign encroachment.

1 The title refers to Bayly, Birth of the Modern World, chapter 3, 86-120; and Armitage and Subrahmanyam, eds, Age of Revolutions. See already the seminal monograph published in 1962 by Hobsbawm, Age of Revolution. 
An intensified attachment to the person and model of the Prophet that often went well beyond common local practice can be found with many of these movements. There are four features of this attachment in particular that will be discussed in the second part of this chapter. The first involves the frequent use of reports on Prophetic sayings and deeds (ahäditth), and their lines of transmission (asānīd), often in combination with similar "chains" (salāsil) leading back to early Sufi masters. The second includes an evocation of spatial links associated with the Prophet's burial place, Medina, and the creation of local memorial landscapes connected with him and his companions. This often contributed to the rise of a local culture of benedictions of the Prophet and to the emergence of a rich poetry in praise of him, in both Arabic and local languages. The third and perhaps most crucial trend reclaimed the Prophet as a model of emulation, and a source of religious and political mobilisation. An orientation that went along with declared attempts to revive and re-establish his sunna, to fight blameful innovations (bida), and to imitate his way of life and that of his companions for personal and collective conduct, including an exodus (hijra) to escape persecution and jiha a d, and sometimes even the establishment of a caliphate. Tales of encounters with the Prophet in dreams would sometimes confirm the calling. Attention will be finally given to the variegated eschatological claims which were put forward by Muslim leaders and their movements: they included expectation of the approaching end of the world, the appearance of the figure of a renewer of religion (mujaddid) at the beginning of the new thirteenth Islamic century, or even the Mahdī. In the Iranian case of the movement of Sayyid 'Alī Muhammad the Bāb (1844-50), it finally went beyond the limits of Islam, opening a new Prophetic era. Of course, any attempt at developing common general perspectives for the widely distant regional cases that we will cover here must remain tentative for the moment.

Islamic Movements and Revolutions and Their Regional and Global Contexts (ca. $1775^{-185}$ )

The following short reference list of the Islamic scholars, brotherhoods, and movements involved in cultural and political reform, and of new Islamic polities that were founded by them, is arranged geographically from West to East and followed by a comparative analysis that locates them in the context of the "revolutionary age" as discussed by some prominent global historians. Their different modes of attachments to the Prophet will then be outlined in the second part of this chapter. 
I. West Africa ${ }^{2}$

- Kunta-Bakkāiyya (Qādiriyya) in the Western Sahara and Niger region $(\text { ca. } 1750-1825)^{3}$

- Imamate of Futa Toro (ca. 1770-1807)

- Imamate of Futa Jalon (founded 1725, consolidation ca. 1770, Imamate $\left.1725^{-1896}\right)^{5}$

- Hamdallāhi Imamate in Masina (1818-64)

- Islamic movement founded by 'Uthmān b. Fōdiye in the Central Sudan $(1774-1817)$, Sokoto caliphate $(1804-1903)^{7}$

- Jihād movement of the Tijānī leader al-Hājj 'Umar (d. 1864) in Senegambia and the Niger region (since 1849$)^{8}$

II. North Africa

- Muhammad b. 'Abd al-Raḥmān Abū Qabrayn (d. 1793) and the spread of the Rahmāniyya in Kabylia and other parts of Algeria; participation in anti-French rebellions since the 184 os $^{9}$

- Aḥmad al-Tijānī (d. 1815) and the spread of the Tijāniyya;"i jihād of al-Hājj 'Umar in Senegambia (see above)

- Emirate and jihād of 'Abd al-Qādir (Algeria, 1832-47) ${ }^{11}$

$2 \quad$ For general overviews of the West African jihād movements, see Last, "Reform in West Africa"; Robinson, "Revolutions in the Western Sudan"; Loimeier, Muslim Societies in Africa, 108-29.

3 Batran, Qadiriyya Brotherhood; Batran, "Kunta”; Willis, "Western Sudan", 555-65; Brenner, "Concepts of Taríqa"; Rebstock, Maurische Literaturgeschichte, vol. 1, no. 552, 155-70.

4 Robinson, Chiefs and Clerics; Robinson, Holy War, 59-71; Ware, Walking Qur'an.

5 Boulègue and Suret-Canale, "Western Atlantic Coast", 522-27; Person, "Atlantic Coast", 273-79; Sow, ed., La femme; Sow, ed., Chroniques; Diallo, Les institutions; Robinson, Holy War, 49-59; Bohas et al., eds, Islam et bonne gouvernance.

6 Bâ and Daget, L'empire Peul du Macina; Brown, "Caliphate of Hamdullahi”; Oloruntimehin, Segu Tukolor Empire; Sanankoua, Un empire peul; Robinson, Holy War, 77-81, 282-316; Loimeier, Muslim Societies in Africa, $122 \mathrm{ff}$.

7 Last, Sokoto Caliphate; 'Uthmān b. Fōdiye, Bayān wujūb al-hijra; Hiskett, Sword of Truth; Usman, ed., Studies; Brenner, "Concepts of Tarīqa"; Adeleye and Stewart, "Sokoto Caliphate"; Hunwick, "Fodiawa", "Other Members of the Fodiawa and the Wazirs", in Arabic Literature, chapters 2-5, 52-212; Mack and Boyd, One Woman's Jihad.

8 Robinson, Holy War; Futi, Voilà ce qui est arrivé; Loimeier, Muslim Societies in Africa, 119-24.

9 Rinn, Marabouts et Khouan, 452-80; Margoliouth, "Rahmāniyya"; Clancy Smith, Rebel and Saint, 33-70, 92-167.

10 Abun-Nasr, Tijaniyya; Abun-Nasr, "al-Tidjānī”; Abun-Nasr, "Tidjāniyya"; Robinson, Holy War.

11 McDougall, "Abd al-Qādir, Amīr”; Bennison, Jihad; Chodkiewicz, Écrits spirituels; Etienne, Abdelkader; Bouyerdene, Emir Abd El-Kader. 
- Muhammad b. 'Alī al-Sanūsī (d. 1859) and the spread of the Sanūsiyya in the Hijāz (1820s), Egypt, Libya, and the Saharan region (since the $18405)^{12}$

III. Arabia and Yemen

- Wahhābiyya (1744-1818) in Central Arabia, founded by an alliance between the emirs of al-Diriyya and the scholar Muhammad b. 'Abd al-Wahhāb (d. 1792) $)^{13}$

- Zaydī reformist scholars in Yemen (al-Amīr al-Ṣanānī, d. 1769, al-Shawkānī, d. 1834) ${ }^{14}$

- Sufi brotherhoods founded by the students of Ahmad b. Idrīs (d. 1837): Muhammad b. 'Alī al-Sanūsī (d. 1859, see above), Muhammad b. 'Uthmān al-Mīrghanī (d. 1852, Khatmiyya in the Sudan), Muhammad Majdhūb (d. 1831, Majādhīb in the Sudan), Ibrāhīm al-Rashīd (d. 1874, Rashīdiyya and other offshoots in Sudan, north-east Africa, Middle East)

IV. Qajar Iran and the Twelver Shīa

- Messianic movement of Sayyid 'Alī Muhammad the Bāb (Iran, $1844-50)^{15}$

v. Russia and the Caucasus

- Muslim Tatars and Bashkirs during and after the Pugachev Revolt $\left(1773^{-} 75\right)$ in the Volga region and in Siberia ${ }^{16}$

- Imamates and anti-Russian struggle in the Caucasus (1820-59) ${ }^{17}$

VI. Naqshbandiyya in Central Asia and north-west China

- Mangit rulers in Bukhārā (Shāh Murād und Emir Ḥaydar, 1785-1826) ${ }^{18}$

12 Vikør, "The Sanūsiyya Tradition"; Vikør, Sufi and Scholar; Vikør, "Sources for Sanūsī Studies"; Triaud, "al-Sanūsī"; Triaud, "Sanūsiyya".

13 Rentz, Birth of the Islamic Reform Movement; Peskes, Muhammad b. Abd al-Wahhāb; Peskes, "Wahhābiyya"; Peskes, "Wahhābiyya and Sufism"; Peskes, ed., Wahhabism; Mouline, Clerics of Islam; Currie, "Kadizadeli Ottoman Scholarship"; Chapter 2 in this volume.

14 Radtke et al., The Exoteric Ahmad Ibn Idrīs, 19-23; Haykel, Revival and Reform; Dallal, Islam without Europe; Pink, "Where Does Modernity Begin?".

15 Amanat, Resurrection and Renewal; Amanat, Iran, 236-49; MacEoin, "Babism"; MacEoin, Messiah of Shiraz; Lawson, Gnostic Apocalypse; Eschraghi, Frühe Šaihī- und Bābì-Theologie. The Bābī movement is mentioned already by Hobsbawm, Age of Revolution, 225.

16 Longworth, "Pugachev Revolt"; Peters, Politische; Kemper, Sufis und Gelehrte; Frank, Islamic Historiography.

17 Gammer, Muslim Resistance; Kemper, Herrschaft; Kemper, "Daghestani Legal Discourse"; Sidorko, Dschihad im Kaukasus.

18 Schefer, Histoire; von Kügelgen, Legitimierung. 
- Khafiyya and Jahriyya Naqshbandīs and their struggles in northwestern China (Ma Laichi, d. 1753, Ma Mingxin, d. 1781) ${ }^{19}$

VII. South Asia

- School of Shāh Walī Allāh (d. 1762) of Delhi and his descendants; jihād of Sayyid Ahmad Brēlvì (d. 1831) in northern India ${ }^{20}$

- al-Hājj Sharīat Allāh (d. 1840) and the Farāizịī movement in eastern Bengal $^{21}$

VIII. South East Asia

- Padri movement and revolt in Sumatra $\left(1803^{-37}\right)^{22}$

- Anti-Dutch revolt led by Dipanagara, prince of Yogyakarta, in Java $(1825-30)^{23}$

\subsection{Transregional Commonalities and Convergences within the "Age of Revolutions"}

The remarkable number of new political and religious movements, upheavals, and even revolutions that unfolded in the Muslim world in the eighteenth and early nineteenth centuries - remarkable for their simultaneity as well as for their local diversity - found the increasing attention of Islamologists, historians of Africa, and also of global historians, since the 1980s. A list of these developments (including those of the later nineteenth century) can already be found in Ira Lapidus's History of Islamic Societies (first ed. 1989). ${ }^{24}$ Discussions among Islamologists on Sufi and anti-Sufi reformism which arose in the different Muslim regions in connection with the mentioned movements had begun earlier with the debate on "Neo-Sufism" and on Islamic reformism, during which the far-reaching scholarly networks linking the different movements

19 Fletcher, "Naqshbandiyya”; Aubin, "En Islam chinois”; Lipman, Familiar Strangers, 64-72, 85-115; Sobieroj, "The Chinese Sufi Wiqāyatullāh"; Sobieroj, "Spiritual Practice".

20 Rizvi, Shāh Wali-Allāh; Baljon, Religion and Thought; Hermansen, Conclusive Argument; Hermansen, Shah Wali Allah's Treatises; Dallal, Islam without Europe; Rizvi, Shâh 'Abd al'Azîz; Ahmad, Wahhabi Movement; Gaborieau, Le Mahdi incompris.

21 Ahmad Khan, Fara'idi Movement.

22 van Ronkel, "Inlandsche getuignissen"; Dobbin, Islamic Revivalism; Suryadi, "Shaikh Daud of Sunur"; Wieringa, "A Tale of Two Cities"; Hadler, "Historiography of Violence"; Zakaria, "Landscapes and Conversions".

23 Carey, Prophecy; Carey, Destiny; Florida, Writing the Past; Dutton, ed., Voices of Southeast Asia, 99-109.

24 Lapidus, History, table 16, 566ff. (1st ed.), 517 (3rd ed.). 
had already gained attention. ${ }^{25}$ The Islamic reformist tracks of the eighteenth and early nineteenth centuries, which challenged the Sunnī legal schools as much as popular religious culture, were pursued by scholars like Shāh Walī Allāh, Muḥammad b. 'Abd al-Wahhāb, 'Uthmān b. Fōdiye, Shawkānī, and Sanūsī well before the impact of Europe on their different home regions. This has been brought once more into sharper focus by the recent works of Ahmad Dallal. ${ }^{26}$

Global historians like Christopher Bayly, David Armitage, and Sanjay Subrahmanyam have also reflected on the role of the Muslim regions in the "Age of Revolutions". ${ }^{27}$ Taking the Seven Years War (1756-63) as their point of departure, Armitage and Subrahmanyam stress the interconnectedness of the economic and political turbulences of this era, which amounted to a threefold revolution in geopolitics, culture, and economics in large parts of the Eurasian world. ${ }^{28}$ Bayly describes the late eighteenth and the early nineteenth centuries as an age of "converging revolutions", ${ }^{29}$ whose roots he traces back to the deformation, decline, or even breakdown of the Muslim empires in Asia, and to the devastating impact of Nadir Shah's invasion on the Mughal Empire. Historians of Safavid and post-Safavid Iran have argued that his success was based on a veritable military revolution in terms of drill, discipline, and army size, and on novel techniques and strategies in the use of firearms. ${ }^{30}$ Although this revolution remained unfinished due to Nadir Shah's death, it led to changes in the balance of power in the Middle East as well as in Central and South Asia. This sparked European competition and warfare in the Indian Ocean region, with far-reaching consequences for both America and Europe itself, contributing to the grave economic crises and the ensuing revolutionary changes of the late eighteenth century. At the same time the legitimacy of the Muslim states was thoroughly sapped, leading to far-reaching efforts by Muslim scholars and religious movements from elite as well as from middle-class and rural strata to redefine the sources of moral, political, and economic order - an observation that could be easily extended to other Muslim regions. For the West

25 For critical overviews of these debates, see Sedgwick, Saints and Sons, 9-82; Chih, Sufism in Ottoman Egypt, 77-89; Knysh, New History, 5 off.

26 Dallal, "Origins"; Dallal, Islam without Europe.

27 See Armitage and Subrahmanyam, "Introduction"; Bayly, Birth of the Modern World, 27-120; Bayly, "Age of Revolutions". Hobsbawm, Age of Revolution, 223ff., also discusses "the ferment and expansion of Islam" in the period in question.

28 Armitage and Subrahmanyam, "Introduction", xviiiff., quoting Darwin, After Tamerlane.

29 Bayly, Birth of the Modern World, chapter 3, 86-120; see also Travers, "Imperial Revolutions", $145 \mathrm{ff}$.

30 See for this Axworthy, "The Army of Nader Shah", building on the works of Rudi Matthee. 
African case, the impact of the Atlantic slave trade on Muslim states and societies, and on Muslim religious and political reformism in the region, has been highlighted in a recent comprehensive study by Paul Lovejoy. He describes the emergence of large-scale slave economies in the newly established Islamic states in West Africa. This development is seen by him as a strategic withdrawal from the European commerce of slaves in the Atlantic world that went along with attempts to protect Muslims from enslavement, to restrict the trade to non-Muslim slaves, and to channel a major part of them into the expanding economy of the new Islamic states themselves. But he also demonstrates the repercussions of the Muslim revolutionary movements on the slave communities in America. ${ }^{31}$

The great significance of Sufi movements for many political transformations is particularly notable. The emirate of 'Abd al-Qādir in Western Algeria (1832-47) sprang from the activities of the Qādiriyya zāwiya of his father. The founders of the Tijāniyya and Rahmāniyya were strongly influenced by the Egyptian Khalwatiyya before establishing their own centres in Algeria and Morocco. The Sanūsiyya originated from an Algerian scholar who underwent Sufi instruction and scholarly training mainly in Morocco, Egypt, and the Hijāz and then built up a followership in Egypt, Libya, and the Sahara. In West Africa the Qādiriyya branch of the Kunta Bakkāiyya of Tuwāt and Azawad with its leader, Sīdī Mukhtār al-Kuntī (d. 1811), managed to form a far-reaching trans-ethnic network of Sufi allegiances and trade partners under a central leadership which provided a model for later popular - and more militant movements in the Niger region and further west. Qādirī affiliations were also influential in the Fulbe jihād in Futa Toro (Senegal, 1776-1861), Futa Jalon (Ivory Coast, 1725-1896), Ḥamdallāhi (present-day Mali, 1818-62), and especially in the Sokoto caliphate (present-day Nigeria, 1804-1903). The jihād of the Tijānī leader al-Hâajj 'Umar (d. 1864) equally unfolded in Senegambia: it was based on the spread of the Tijāniyya Sufi order from North Africa to the Saharan and sub-Saharan regions since the early nineteenth century.

In Central Asia, it was the Mangit ruler Shāh Murād (1785-18oo), emir of Bukhārā, who thoroughly transformed his state along Islamic lines in close allegiance with the Naqshbandiyya Mujaddidiyya. In China, two branches of the same tariqa which were introduced by scholars who had spent some time in the Yemen and Hijāz became enmeshed in the local ethnic conflicts in the north-western provinces (especially Gansu), and in the upheavals that followed the Chinese conquest of Xinjiang (1757-59): the two groups were committed to different forms of dhikr (the "silent" [khafi] versus the "loud" [jahrī])

31 Lovejoy, Jihād in West Africa, esp. 102ff. 
that were widely discussed at the time. They ran into fierce disputes with each other, which finally brought the Jahriyya of Ma Mingxin into violent conflict with the imperial government. The Jahriyya, whose leader was executed in 1781, survived underground and in emigration; they propagated a cult of martyrdom and participated in several other local uprisings well until the end of the empire.

In the Volga region since the late eighteenth century, a similar trend is attested, originating among Tatar scholars and traders and spreading within their extended diaspora. They were also committed to the Naqshbandiyya and, after the Pugachev revolt in which many Tatar peasants and a good number of local scholars had been involved, they responded to the new institutional Islamic framework (with officials recognised by the state) that had been created by Catherine II, with a Sufi and ethical reformism and with intense educational activities.

Further cases of the nineteenth century included the jihâd states which were formed as polities guided by the shari $a$, in direct reaction to European imperial expansion in Algeria (against France, 1832-41) and in Dāghistān (against Russia, 1818-59). The Sufi allegiances of their leaders remained strong and in Dāghistān even shaped their military organisation. Comparable to the Kunta, the Sufi and trading network of the Sanūsiyya brotherhood (founded in 1832) extended from Libya into the Saharan and sub-Saharan regions, already before it was drawn into the struggle against Italian and French encroachment. A thorough Sufi basis of preaching and mobilisation is documented for Sayyid Aḥmad Brēlvī and Sayyid Ismāî̀ Shahīd (both d. 1831) and their jihād movement in northern India, which even after its dispersal remained influential until the Great Mutiny against British rule that finally terminated the remnants of the Mughal Empire (1858-59). A strong Sufi affiliation is also documented for al-Ḥājj Sharīat Allāh (1781-1840) in East Bengal, a Qādirī Sufi trained in Mecca, and his struggle against local popular rites and ceremonies which he regarded as bid'a, and against oppressive taxes for the support of Hindu festivals that were exerted on the rural Muslim population by Hindu landlords.

In line with the revival of political thought and "popular claim-making" which, as noted by Bayly, ${ }^{32}$ was quite common in this age, many of the newly founded movements and polities attempted to introduce novel and quite remarkable forms of statehood and political representation in multi-ethnic and stratified Muslim communities. Their political orders were backed and legitimised by the theological and juridical writings of their leaders. This can be observed for the Fulbe imamates of Futa Jalon and Ḥamdallăhi, which 
developed elaborate institutions of consultation and representation for the different regional and social groups that were attached to their polity. Similar regional and tribal federations subject to sharîa law were established by the imamate of Shāmil (d. 1871) in the Caucasus, and in the emirate of 'Abd al-Qādir in Algeria. In Central Arabia, the novel type of emirate which was founded in 1744 by the Āl Su'üd in close partnership with the radical Sunni scholar Muhammad b. 'Abd al-Wahhāb (d. 1792) remained an influential ideological model for others in later times, well until the present. Whereas it shared the fierce critique of many popular religious customs with other, Sufi-based movements, it was resolutely critical of the Sufi orders and of many core elements of Sufi practice itself.

Even in the context of the Zaydì imamate of the Yemen, a legal framework based on the Qurān and hadìth and a thorough critique of the imitation (taqlïd) practices within the legal schools was elaborated by Shawkānī, the Chief Qàdị of Șan`ă', apparently with view to the Sunnì majority of its population. He had entertained strong sympathies for Muhammad b. 'Abd al-Wahhāb before he was alienated from him because of the destructions of Islamic religious sites and the radical treatment of many other Muslims as unbelievers which were propagated and practised by the Wahhābī state. ${ }^{33}$

Attempts at the foundation of new caliphate states as all-embracing religio-political institutions are also attested for different regions. A caliphate emerged in the Sokoto state, where it served as an umbrella for a number of emirates covering a vast area of the Central Sudan, with an economic sphere of influence that reached far beyond its political realm. Caliphates of a more utopian character were envisaged by Sayyid Ahmad Brēlvī for northern India, Afghanistan, and Central Asia, and by Prince Dipanagara of Yogyakarta, who intended to establish himself as a sacred leader of the Muslims in Java and as a protector of their interests vis-à-vis the Dutch.

Several of the movements just mentioned were led or inspired by local scholars who called for an Islamic political and cultural revival. They often denounced a number of deeply rooted religious and cultural customs or suppressive taxes which they declared un-Islamic, and they strongly criticised rulers who supported these practices. At the same time, they can be seen as responding to the political crises which were unfolding in different Muslim regions in consequence of the decline and breakdown of the regional and imperial political order. Many of them were Sufi leaders, like Mukhtār al-Kuntī or Ahmad b. Idrīs. Disciples of the latter founded several Sufi orders, some of 
which became highly influential organisations. A good number of the newly founded polities developed their own patters of political representation in multi-ethnic Muslim communities that were argued for and legitimised by the theological and juridical writings of their leaders. The establishment of Muslim statehood on this Islamic ideological base often went along with largescale preaching activities and with the rise of a literary culture in Arabic as well as in local languages.

These examples of Islamic revolutionary and reformist movements and struggles exclude the military and administrative reforms initiated in the Ottoman Empire and Egypt in this period, sometimes rightly labelled as revolutions from the top (occasionally directed even against their own societies), and also the far-reaching changes initiated by the Moroccan and Tunisian rulers in the same period. ${ }^{34}$ They may suffice here to illustrate both the extension and the strongly religious and often Sufi colouring of the profound sociopolitical changes which coincided with the American and European revolutions, and with European imperial expansion.

The religious character of many of these movements and revolutions in the Muslim regions would at first sight set them apart from the Euro-American revolutions of the period, whose strongly secular character has remained a major reference point for later generations. But it might be worth remembering the great religious revivals whose impact on the American Revolution has been widely recognised, ${ }^{35}$ and which are also attested elsewhere both among Protestants and Catholics in the early nineteenth century. ${ }^{36}$ The nationalist movements which emerged in different parts of Europe in the early nineteenth century, and also the early socialists, made frequent use of religious symbols and identities. ${ }^{37}$ The millenarianism connected with the American

34 For a short overview and critical evaluation of the reforms of Selīm III and Mahmūd II, see Neumann, "Political and Diplomatic Developments", esp. 6o-64; for Muhammad 'Alī in Egypt, see e.g. Fahmy, "The Era of Muhammad 'Ali Pasha"; for Morocco and Tunisia, see Harrak, "State and Religion"; El Mansour, Morocco in the Reign of Mawlay Sulayman; Bennison, Jihad; Abun-Nasr, History of the Maghrib, 179-87, 239-47, 297-301.

35 Marty, "American Revolution"; Ward, "Evangelical Awakenings"; Brown, "Movements of Christian Awakening”; Hochgeschwender, Amerikanische Revolution; Hochgeschwender, Amerikanische Religion, esp. 61-76. For Christian religious developments during the "Age of Revolution" in America and Europe, see already chapter 12 of Hobsbawm, Age of Revolution, 217-33.

36 Tackett, "French Revolution"; Desan, "French Revolution".

37 See the remarks by Friedrich Engels in his essay "Zur Geschichte des Urchristentums" (written in 1894), 449-54; also Strube, Sozialismus, Katholizismus und Okkultismus. 
Revolution ${ }^{38}$ and even with the revolutionary ideology in France ${ }^{39}$ might lend itself for comparison with the religious eschatological expectations that were equally current at the time among Muslims, Jews, and Christians. It appears therefore justified to treat the remarkably wide range of the mentioned Islamic movements and the novel forms of statehood that were established by them equally as part of the global historical transformations of that period.

\subsection{The Significance of the Prophet for Islamic Reformist and Revolutionary Movements: An Attempted Exploration}

We now return to the observation, stated at the beginning, that many of the Islamic scholars and movements that we have mentioned propagated a strong commitment to the Prophet and his sunna as a base for community building and political legitimacy, and manifest the four features which were already mentioned above and which appear to be central for this orientation. Their leaders had strong roots in their own society and culture; at the same time, they were often looking towards the religious centres of the Muslim world, especially to Medina, for their normative models. Some of them developed novel forms of public preaching and writing in vernacular languages and embarked upon a fight against perceived "blameful innovations" that often led to militant political action. Sufi and anti-Sufi orientations as well as strong eschatological expectations could be found among them. Many of the earlier movements, as we have seen, were first committed to local sociopolitical changes and transformations before being drawn into the struggle with the increasing European expansion. Others were directed from the start against European dominance and occupation.

\subsubsection{Hadith and Sufi Transmissions}

A renewed and invigorated focus on the study and transmission of the Prophetic tradition (hadith) can be observed in Muslim religious scholarship in various parts of the Muslim world since the second half of the seventeenth century. It gained in momentum in the course of the eighteenth century among scholars in regions as distant as the Maghrib and India, with the Holy

38 Cf., for North America the motto "A New Order for the Ages" (Novus ordo seclorum) inscribed on the great seal of the US, Bloch, Visionary Republic.

39 Caffiero, "Prophétie, millenium et révolution", with reference to Starobinski, 1789; Ouzouf, La Fête révolutionnaire; and Vovelle, La mentalité révolutionnaire; Schlobach, "Fortschritt oder Erlösung". 
Cities of the Hijāz emerging as perhaps the most active centres of hadìth studies. ${ }^{40}$ It has often been stated that the reinvigoration of these studies provided the basis for the Islamic religious and political activism of the late eighteenth and early nineteenth centuries. Khaled El-Rouayheb has recently expressed some doubts over the novelty of this pious interest as well as over its "revivalist" or "reformist" character. ${ }^{41}$ The prominent hadith scholars of seventeenth-century Hịjāz, the Maghribīs 'Īsā al-Tha'ālibī (d. 1669) and Muḥammad b. Sulaymān al-Rūdānī (d. 1683), the Medinan Șafì al-Dīn al-Qushāshī (d. 1661), and the Kurdish scholar Ibrāhīm al-Kūrānī (d. 169o) were certainly all-round scholars who combined their interests in the Prophetic tradition with a profound knowledge of logic and the rational sciences and with a strong Sufi orientation. But they trained a whole generation of famous hadìth scholars of the early eighteenth century like 'Abd Allāh b. Sālim al-Bașrī (d. 1721), ${ }^{42}$ Aḥmad al-Nakhlī (d. 1718), Muḥammad b. 'Aqīla (d. 1736), Ḥasan al-'Ujaymī (d. 1702), Kūrānī’s son Abū Ṭāhir al-Kūrānī (d. 1733), and Abū l-Ḥasan al-Sindī al-Kabīr (d. 1726). Bașrī, Ibn 'Aqīla, and Sindī produced new editions of Bukhāri’s Șaḥịh and Ibn Ḥanbal's Musnad, and glosses to the latter book and to most of the canonical collections. Bașrìs student Muhammad Ḥayāt al-Sindī (d. 1750) and his own disciples Abū l-Ḥasan al-Sindī al-Ṣaghīr (d. 1773) and Muhammad Saīd Safar (d. 1780) became equally famous. In the course of the eighteenth century, the philological work of hadith scholars gave a boost to lexicography, with two large commentaries to Fīrūzābādī's Q Qummūs produced by another Moroccan muhaddith in Medina, Muhammad b. al-Ṭayyib al-Fāsī (d. 176o), and by his student Murtaḍā al-Zabīdī (d. 1791), whose commentary, the Bridal Crown (Tāj al-'arūs), which he wrote and finished in Cairo, still remains the largest Arabic lexicon. ${ }^{43}$ Both Rūdānī and Muhammad b. al-Ṭayyib were connected through their teachers to the Zāwiya Dilāiyya (in the Middle Atlas in Morocco), which until its destruction in 1668 had been one of the most important political as well as intellectual centres of the Maghrib and whose teaching activities were continued in Fez by its exiled leading scholars. ${ }^{44}$

40 Development and protagonists of hadith scholarship in Medina in the late seventeenth and eighteenth centuries are extensively discussed by Ince, "Medina im 12./18. Jahrhundert", 291-318.

41 El-Rouayheb, Islamic Intellectual History, $164 \mathrm{ff}$.

42 On him, see Voll, "Abdallah ibn Salim al-Basri".

43 For the role which hadìth plays in Zabīdī's Tāj al-'arūs, see Reichmuth, World of Murtadāa al-Zabìì, 229, 233, 25off., 255 .

44 For the Zāwiya Dilāiyya and Rūdānī, see El-Rouayheb, Islamic Intellectual History, 15off., 161; for Muhammad b. al-Ṭayyib and his studies with a Dilā̄ì scholar in Fez, see Ḥajjī, al-Zāwiya al-Dilā̉iyya, 273. 
The Moroccan and the Indian scholars played an important role within this "school of hadith" in the Hijāz. The work and teaching of the scholars from Sind (now Pakistan) were dominated by a strong orientation towards hadith also in the legal field. Contrary to the majority opinion within the Hanafi school to which they belonged, they resolutely maintained the pre-eminence of hadith over the consensus $(\ddot{j} m \bar{a} \bar{c})$ in legal questions. With their teaching and writing they exerted a strong influence over the discussions on the authority of the legal schools and their limitations, which were gaining in importance in the Middle East and the Maghrib as well as in India in the course of the eighteenth century. In this respect, neither the reformist outlook of some of the most prominent hadith scholars of the Hijāz can be denied, nor their crucial influence upon others in different parts of the Muslim world. The great pride which the Medinan scholars took on the achievements of their own generation in the science of hadith was expressed by one of them (Muhammad Saìd Safar) in a didactical poem on the relation between the Islamic legal schools and the Prophetic tradition. ${ }^{45}$

A further favourite interest of the hadith scholars of those days were the musalsalät traditions, which linked the transmitters by certain acts, utterances, places, or other qualifications, like the famous "hadith transmitted first" (al-hadith al-musalsal bi-l-awwaliyya), the "hadith transmitted with a handshake" (mușäfaha), the "hadith transmitted on the day of Eid", among others. Occupation with musalsalāt transmissions has a long history in hadïth scholarship; ${ }^{46}$ it seems, however, that a number of the largest collections of such musalsalät transmissions were produced in the eighteenth century by scholars belonging or related to the hadith scholars of the Hijāz, like Ibn 'Aqīla, Muhammad b. al-Tayyib, and also Zabīdī, who commented upon and considerably augmented Ibn 'Aqila's collection. ${ }^{47}$ At the same time, it can be observed that the transmission of Sufi turuq and their garments (khiraq) increasingly followed the pattern of the hadīth, with collections of Sufi saläsil equally growing since the seventeenth century. Here again, scholars belonging to the Hijāz circle of hadith scholars seem to have taken the lead. ${ }^{48}$ This trend towards an analogous treatment of isnād and Sufi salāsil seems to reflect an enhanced

45 Risālat al-hudā, quoted by Ince, "Medina im 12./18. Jahrhundert", 307.

46 A comprehensive overview of writings in this field is provided by Kattānī, Fihris al-fahāris, 1:85-94, 2:655-66, with further references to many of the mentioned works under their title; see also Davidson, "Carrying on the Tradition", 123-27.

47 Zabīdī, al-Fawā̉id al-jalīla; al-Tálìqa al-jalīla; see Reichmuth, World of Murtậāa al-Zabìdì, 102,135 .

48 See for this Reichmuth, "Quest for Sufi Transmissions". 
pious attitude towards the chain of transmission leading back to the Prophet, both for his utterances and for the Sufi turuq.

The influential reformist scholars of the eighteenth and early nineteenth centuries in regions as distant as West Africa, Arabia, and South Asia were all related, either directly or through their teachers, to the hadith scholars of the Hijāz. This is documented in an exemplary way for 'Uthmān b. Fōdiye (d. 1816): his two collections of isnāds, a short and a long version of the same material, link him via some teachers who had visited the Hijāz and Egypt to two of the prominent figures of the "Hijāzì school" of hadìth scholarship that were already mentioned, that is, Abū l-Ḥasan al-Sindī al-Ṣaghīr and Zabīīìn ${ }^{49}$ They also refer to them for Sufi transmissions. A connection with Zabīdī can also be established later for the father of the emir 'Abd al-Qādir (for a Sufi silsila leading to Ibn 'Arabī) in Algeria and for some of the teachers of Muhammad b. 'Alī al-Sanūsĩ in Morocco. ${ }^{50}$ One of the teachers of Muhammad b. 'Abd al-Wahhāb (d. 1206/1791) during his stay in Medina was Muḥammad Ḥayāt al-Sindī, another central figure of hadith scholarship in eighteenth-century Medina. ${ }^{51}$

The Tarīqa Muhammadiyya of Sayyid Ahmmad Brēlvī in northern India originated in the school and family of Shāh Walī Allāh in Delhi, who as mentioned had also established links to the hadīth scholars of Medina (in his case to Abū Taahir al-Kūrānī and to Wafdullāh, the son of Rūdānī $)^{52}$ during his stay in the Hijāz. The second leading figure of the movement, Ismāīl Shahīd (d. 1831), was himself a grandson of Wali Allāh and was brought up in his tradition, even if he clearly radicalised his own theological stand beyond that school. This certainly supports Dallal's argument (directed against John Voll and others) that the identification of network relations alone does not explain the ways of thought and action taken by the members of the network, and that the local networks were often more important for scholarly formation than the transregional ones. ${ }^{53}$ But the centrality of the Hijāz school that figures in virtually all the credentials of the important Islamic movements of the time suggests a strong influence of the general pattern of what could be called "hadith piety", which was apparently conveyed by this school. As can be observed in different parts

49 See for this Al-Nagar, "Asānīd of Shehu dan Fodio"; Reichmuth, "Glimpses", 70, 74ff.; Reichmuth, "Murtaḍa al-Zabīdī and the Africans", 138-41.

50 For 'Abd al-Qādir, see Chodkiewicz, Ocean without Shore, 16 ; Reichmuth, World of Murtadā al-Zabìdī, 186; for Sanūsī, see Vikør, "Sources", 7, 23, 35, 40, 42.

51 See for him Voll, "Muḥammad Ḥayyā al-Sind̄̄”; Nafi, "A Teacher of Ibn 'Abd al-Wahhāb"; Ince, "Medina im 12./18. Jahrhundert", esp. 292-304, 308-17.

52 See for the latter the blog by Moosa, "Muwațta' Roundtable". I am grateful to Ebrahim Moosa, who drew my attention to this contact.

See e.g. Dallal, Islam without Europe, 58-63. 
of the Muslim world, this form of an enhanced pious attitude to the hadith could find both Sufi and anti-Sufi expressions.

\subsubsection{Spatial Links, Historical Memory, and Praise Poetry Connected with the Prophet and the Hijāz and with Early Islam}

Although the number of hajj pilgrims from distant regions outside the Middle East was limited in the period before the nineteenth century, pious attachment to the Prophet in the period under consideration often expressed itself in the context of the pilgrimage theme and of the Holy Cities, which included the use of pictures of the Haramayn as spatial links to the Prophet. These were often part of the manuscripts of the Daläil al-khayrāt prayer book whose widespread popularity is attested by manuscripts dating from the eighteenth century in North and West Africa, the Middle East, and South and South East Asia. ${ }^{54}$ Such pictures were also taken home as pilgrimage souvenirs. One fine example is attested in the so-called Prayer Book of the Imam Bonjol (d. 1864). He was one of the militant Padri reformists in Sumatra in the 1820s. The book is now kept in the Leiden University Library. Even if its provenance from this man is now strongly in doubt, it nevertheless offers many insights into the Prophetic piety and the eschatological orientation prevailing in the region in those days. ${ }^{55}$ Besides the Daläil al-khayrāt (dated 1229/1814) it includes a number of separate pictures of the Haram of Medina, the tombs of the Prophet and the first caliphs, the palm trees of Fantima, the ceremonial parasol and the flag of the Prophet ${ }^{56}$ and the dead coming out of their graves at Judgement Day, all in a local style with a highly symbolic iconography, apparently for talismanic use. ${ }^{57}$ Three of them, completely imaginary views of the mosque of the Prophet and his tomb (Figure 3.1) and of his flag (Figure 3.2) and parasol (Figure 3.3), are presented here.

For the Padri movement, the religious standards which they had found at the Holy Cities loomed large in their preaching and argument. An early guide

54 See the list and description of mss of the Daläil al-khayrāt from different regions in Witkam, Vroomheid en activisme, 137-61, where the oldest Ms, originating from Turkey, is dated 1704. Further manuscripts from other regions like Central Asia might certainly be added to this collection.

55 Leiden University Library, M. Or. 1751; for a description of its content, see Wieringa, Catalogue, 111-14; Witkam, Inventory, $233 \mathrm{ff}$.

$5^{6}$ For Ottoman pious images of the flag of the Prophet dating from the eighteenth century, see the contribution of Tobias Heinzelmann to the first volume of this series.

57 Leiden University Library, Ms. Or. 1751, fols. 107-8, 125-26, 127-28, 129-30; Witkam, "Images of Mecca and Medina", fols. 8, 9; Witkam, "Hajj Manuscripts", fols. 8, 13, 16, 18. For the historical significance of the Prophet's mosque in Medina in general, see Behrens, "Ein Garten des Paradieses". 


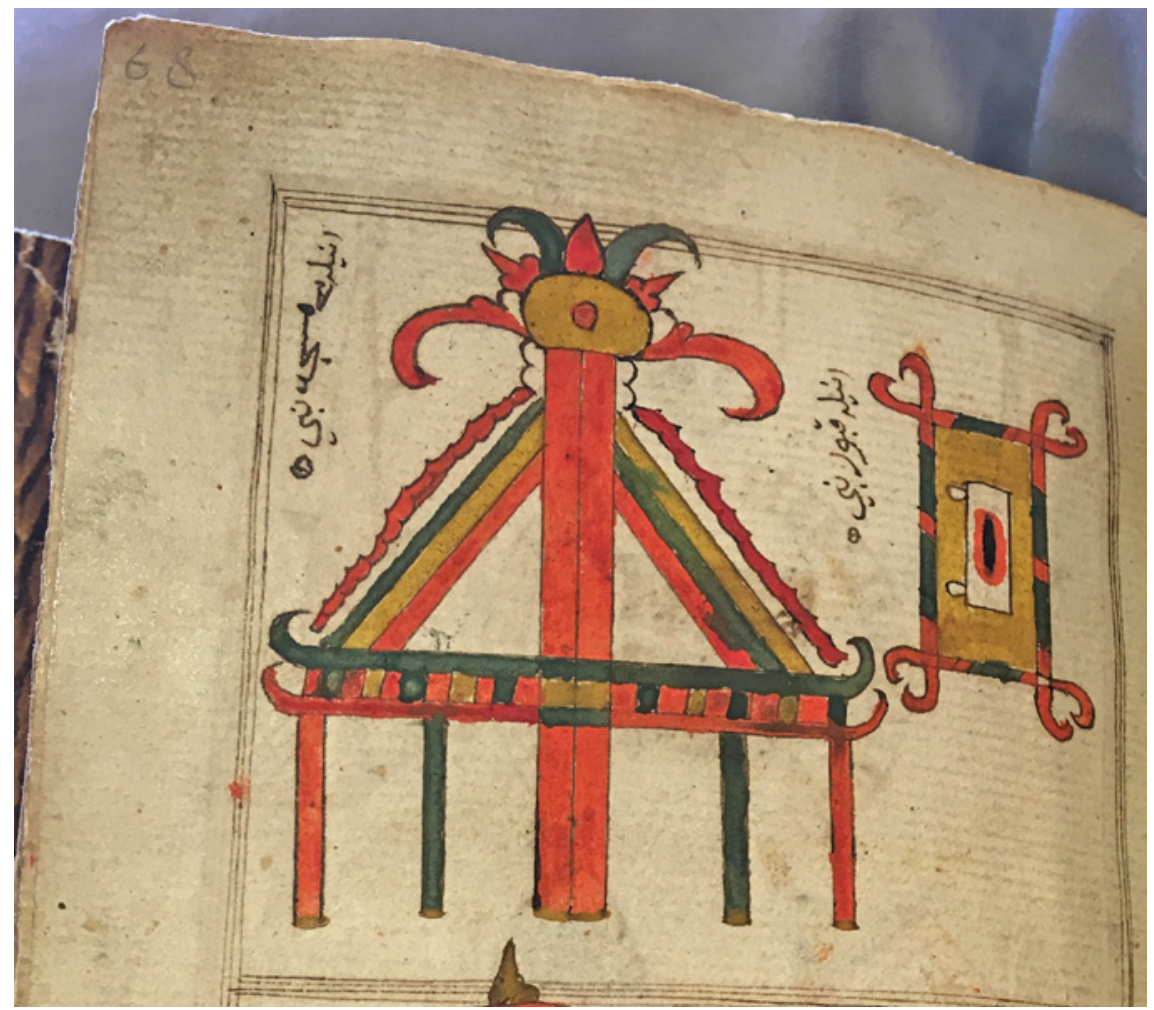

FIGURE 3.1 Imaginary view of the mosque of the Prophet and his tomb (in Malayan style), from the so-called Prayer Book of Imam Bonjol (ca. 1229/1814), Leiden University Library, Ms. Or. 1751, fol. 126

to the Holy Cities in Malay verses, including a strong critique of local Sufi concepts and practices, was written in the 1820 s by another reformist scholar of Sumatra during his stay in the Hijāz. ${ }^{58}$

Local depictions of the Haram of Medina with the Prophet's tomb are equally attested for Mali and for Ilorin, the capital of the southernmost emirate of the Sokoto caliphate. ${ }^{59}$ The picture sheet (Figure 3.4) most probably dates back to the early nineteenth century and was apparently used for both meditation and prayer and as a charm, in order to secure God's forgiveness and to ensure power and success in life. It depicts the Haram of Medina with the tombs of the Prophet and of the two first caliphs, and the central compound

$5^{8}$ Wieringa, "A Tale of Two Cities".

59 For Mali, see Bravmann, "Fragment of Paradise"; for Ilorin, see Reichmuth, "Literary Culture", 235-39; picture taken in 1987. 


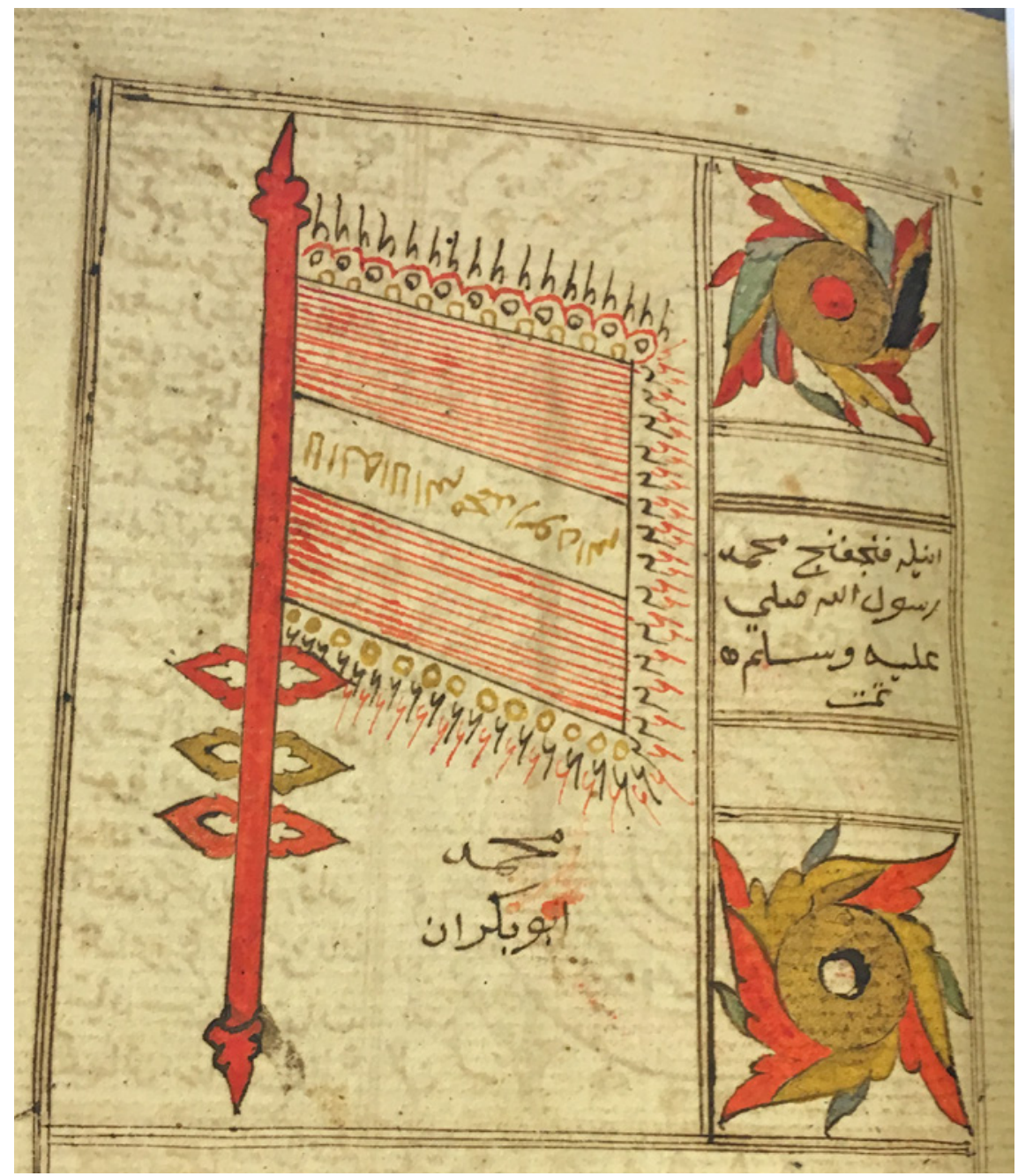

FIGURE 3.2 Imaginary view of the flag (panji-panji) of the Prophet and of Abu Bakr, from the so-called Prayer Book of Imam Bonjol (ca. 1229/1814), Leiden University Library, Ms. Or. 1751, fol. 108

with the imagined houses of his wives and daughters, and of his sons and companions. It also indicates some other important places like the prayer niche, the trees of the Rawdia, and the palm tree of the Prophet. As in the Sumatran case, the drawing shows highly geometrical forms, which suit its specific visual and spiritual functions.

A Dāliyya poem of longing for a visit of Medina and the Prophet and his tomb, which was among the earliest writings of 'Uthmān b. Fōdiye (written already in 1774), and a similar amplified poem in Fulfulde (written in 1805, later 


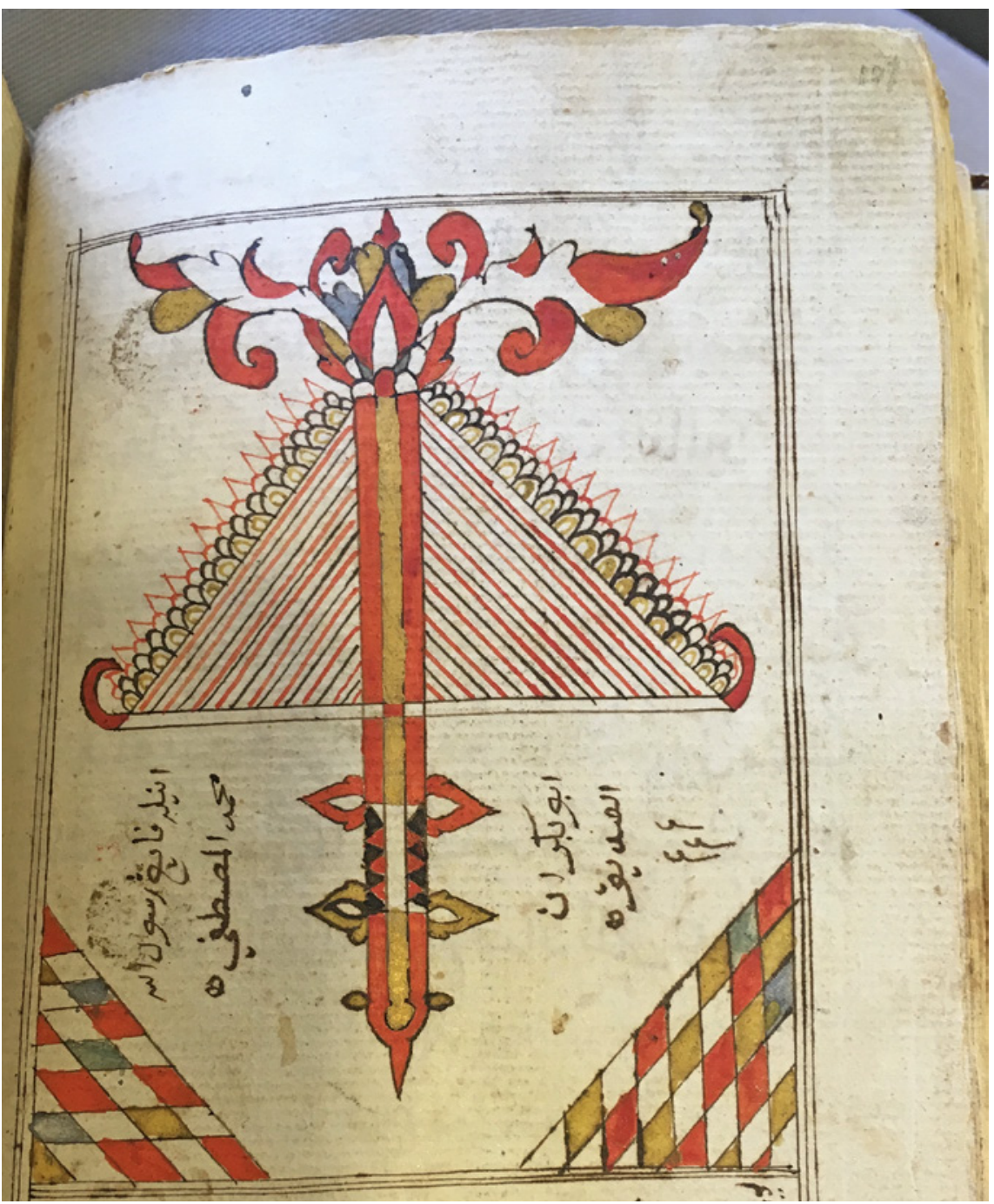

FIGURE 3.3 Imaginary view of the parasol (payung) of the Prophet (Muhammad al-Mușțafā) and of Abū Bakr al-Ṣiddīq, from the so-called Prayer Book of Imam Bonjol (ca. 1229/1814), Leiden University Library, Ms. Or. 1751, fol. 107

translated into Hausa by one of his sons), belonged to the most popular poetic texts in the caliphate. ${ }^{60}$ Nana Asma'u (d. 1864), 'Uthmān's daughter, herself a highly educated and a prolific author in Arabic, Fulfulde, and Hausa, also

6o Hunwick, Arabic Literature, 68, no. 51, 108, no. 79: takhmīs by his brother 'Abdullāhi; the Fulfulde poem (titled Ma'ama'are) in the Hausa translation of his son, with English translation by Graham Furniss in Sperl and Shackle, eds, Qasida Poetry, 2:372-87. 


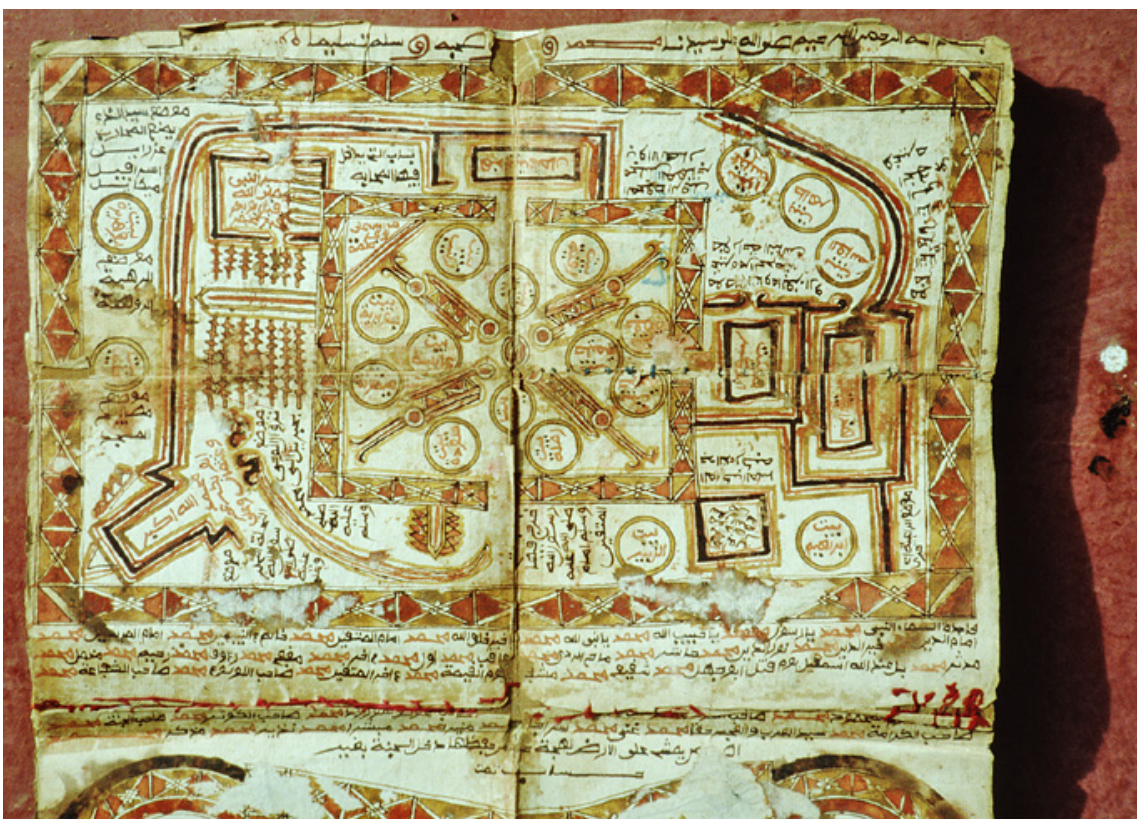

FIGURE 3.4 Medina imagined (Ile Kasandubu, Balogun Fulani Ward, Ilorin, Nigeria): description in Reichmuth, "Literary Culture", 236-39

composed several poems in praise of the Prophet, expressing her own longing for a visit to him in Medina. ${ }^{61}$ Comparing in other poems the eventful career of her father with that of the Prophet, she evoked the image of Sokoto and its community as a second Medina. Poetry in praise of the Prophet in the Fulfulde language, including expressions of longing for Medina, also became popular in Futa Jalon in the early nineteenth century. Deriving its themes and models from an already well-developed tradition of Arabic learning which included famous panegyrics of the Prophet, it became instrumental in linking oral and literary culture within the imamate. ${ }^{62}$

Attachment to the Prophet also gained a spatial dimension in West Africa: new settlements named Makka, Madina, or Tayba became a significant feature of those parts of the savannah landscape which were affected by the jihād

61 See on her especially Mack and Boyd, One Woman's Jihad, with a collection of her poems in English translation.

62 For the religious poetry in praise of the Prophet in Popular/Fulfulde and its cultural role in Futa Jalon, see Seydou, "Poésie religieuse"; Sow, ed., La femme, 45-55; Bohas et al., eds, Islam et bonne gouvernance, 21-26. Apart from Būṣīī’s Burda poem, the Ishrīniyyāt poems of Fazāzī (d. 123o) and their amplification by Ibn Mahīb (d. 1247) were of particular importance in the Western and Central Sudan. 
movements in the Senegal and Niger regions. ${ }^{63}$ This model could also affect the shape of mosque buildings. One of the oldest Friday mosques in Ilorin, said to have been established by the founder of the Islamic movement in the city, shows a central courtyard between two prayer halls; a design that seems to be unique for mosque buildings in the region. According to the tradition of the imam's family it had been built in imitation of the Prophet's mosque in Medina. As the town became the centre of an exodus (hijra) for Muslim slaves from the Yoruba regions, the utopian model of a Medinan community, which we already saw in operation in Sokoto, might have been underlying the shape of this mosque in Ilorin as well. ${ }^{64}$

The spatial and ethnic reorientation which went along with the West African Islamic movements included some efforts by activist scholars to trace their origins to some early Islamic figures and even to the Prophet and his family. 'Uqba b. Nāfic, the companion who had led the major campaigns of Muslim conquest in Ifrīqiyā and in other parts of North Africa, was claimed as an ancestor by the Kunta. They were joined in this by the Fulbe, to whom most of the jihād leaders belonged. ${ }^{65}$ Another version of the descent of the Fulbe from Jafar b. Abi Țālib was backed by the authority of Zabīdī. ${ }^{66}$ Other local traditions collected in Senegambia in the early nineteenth century related a visit of the Prophet himself to their region - apparently in the course of his celestial journey: he was said to have prayed there and to have left the imprint of his knees on the local rocks. ${ }^{67}$ The emergence of an Islamic identity of the Fulbe as a chosen people, and the reassertion of a special religious status by groups which until then had been living under the conditions of cultural and social marginality, clearly comes out in these statements. In the words of David Robinson, "the Central and Western Sudan were ceasing to be a frontier of the faith; they were entering into the Islamic heartlands." 68

A similar development can be found among the Tatars under Russian rule in the Volga region since the late eighteenth century. ${ }^{69} \mathrm{In}$ the local historiography of that period, their origins are moved backwards from the Mongol khanates to the ancient Muslim town of Bulghār at the Volga, which had been founded much earlier and whose remains include a number of old Muslim tombs. Its origin was traced back to three visiting companions of the Prophet. The

\footnotetext{
63 Robinson, Holy War, 85 .

64 See for this Reichmuth, Islamische Bildung, 33ff.; Reichmuth, "A Regional Centre", $232 \mathrm{ff}$.

65 Robinson, Holy War, 81-85.

66 Reichmuth, "Murtaḍā al-Zabīì̄ and the Africans", 140.

67 Robinson, Holy War, $88 \mathrm{ff}$.

68 Robinson, Holy War, 89.

69 See for this Frank, Islamic Historiography; Kemper, Sufis und Gelehrte, 315-54.
} 
Bulghārī identity, which was now adopted, allowed to circumvent the Mongol past of the defeated khanates and to maintain instead a local sacred Islamic landscape under Russian rule.

In the Chinese case of the Naqshbandiyya groups of the Khafiyya and Jahriyya, introduced to north-western China around the middle of the eighteenth century, the journeys of their founders to the Middle East and their stay in Yemen and in the Hijāz became an important element in the memorial culture of their adherents. In the case of the Khafiyya, the founder, Ma Laichi (d. 1753), is linked in a local account ${ }^{70}$ to a prominent Naqshbandī scholar in Mecca, Muhammad Jibuni Ahmad Agelai. This name can probably be identified with Muhammad b. Ahmad 'Aqila (d. 1737), the Meccan scholar and Sufi who was already mentioned above. For Ma Mingxin (d. 1781), the founder of the rival Jahriyya who reached the Middle East a decade later, a connection to 'Abd al-Khāliq b. Zayn al-Mizjājīi (d. 1740) in Zabīd in Yemen, a Naqshbandī proponent of the "loud dhikr", was already identified by Fletcher on the basis of local narratives. ${ }^{71}$ Both Ma Laichi and Ma Mingxin are related to have brought their diverging dhikr forms together with some other texts and prayers from their travels, which they had received from their respective Arabian masters. Among those awarded to Ma Laichi was a Mawlüd text, whereas Ma Mingxin is said to have brought with him a Persian amplification (Chin. muhanmaisi, Ar. mukhammas) of Būṣīī’s famous "Mantle Ode" by Muhammad Tabādkānī(d. 1486), ${ }^{72}$ which became part of the festival ceremonies and the daily recitation of the Jahriyya followers. ${ }^{73}$ An orientation towards the Yemen and the Hijāz, together with the commemoration of the Prophet in Mawlüd and Burda recitations thus played a central role in these two branches of the Naqshbandiyya which were established in eighteenth-century China.

\subsubsection{Imitation of the Prophet and Political Mobilisation}

A common denominator of almost all movements discussed here was their advocacy of a revival of the sunna and a fierce critique of local Muslim practices which were branded as "blameful innovations" (bida). This could include

\footnotetext{
70 Lipman, Familiar Strangers, 64ff., see esp. 67n22, from where the transliteration of the name was taken.

71 Lipman, Familiar Strangers, 85ff.; Fletcher, "Naqshbandiyya", 24-31; for further discussion of the Mizjājī connection, see Sobieroj, "The Chinese Sufi Wiqāyatullāh", 142, 145ff.

72 On him, see Gross and Urunbaev, "Introductory Essays", 81ff.

73 For the Mawlüd given to Ma Laichi, see Lipman, Familiar Strangers, 67n22; for the muhanmaisi, said to have been introduced by Ma Minxin, and its use by the Jahriyya, see Sobieroj, Variance, 99, 101; Sobieroj, "The Chinese Sufi Wiqāyatullāh", 142; cf. Aubin, "En Islam chinois", 555 .
} 
social practices related to marriage and entertainment, to the established protocol of royal courts, but also to Sufi ritual and to the veneration of the tombs of Muslim saints. This was already widely discussed among scholars in the Holy Cities, in the Yemen, and in several other regions, where the call for a return to the sunna strongly increased in the eighteenth century. The literature produced on this topic by those scholars and by the intellectual leaders of the mentioned movements is abundant. ${ }^{74}$ Several of them, like 'Uthmān b. Fōdiye, his junior brother 'Abdullāhi and his son Muhammad Bello in Sokoto, al-Ḥājj 'Umar al-Fūtī in Senegambia and the Niger region, and Ismāî̀l Shahīd, can be found reflecting their own career and the course of their movement as a process of imitation of the Prophet which they lay out in their writings. The Wahhābi movement also had its early historians who followed that track, with Muhammad b. 'Abd al-Wahhāb using his own account of the sirra of the Prophet for that purpose. ${ }^{75}$

The changes in the field of popular claim-making and in the search for new regional political and economic orders that were qualified by Bayly as major characteristics of the "Age of Revolutions" 76 are reflected in the Muslim world in a remarkable number of new forms of regimes that were declared to follow Prophetic and early Islamic models. Several of their founders and leaders were religious scholars themselves and reflected and defended their political opinions and actions in their writings. As mentioned above, they also embarked upon large-scale public preaching activities that developed into mass events in both West Africa and northern India and were a major tool of propagation for their movements in Arabia and Sumatra. The reformists' critique presented a challenge to Muslim kings and court scholars, to the established legal schools, and to Sufi leaders and their communities, and they finally clashed with the growing European presence in their regions. Increasing confrontation with their adversaries often led to a withdrawal from society, to a militant commitment to an authentic Islamic community, and to the establishment of an Islamic state along imamate or caliphate lines. The experience of the evolving struggles was often framed after the model of the Prophet himself, as a $d a^{c} w a$ followed by a struggle against evil rulers and scholars, leading to exodus (hijra) and to a final victory for Islam. As elaborated in their writings, sira and hadith provided the base for an integrative model of individual and collective

74 For further reference, see the books and articles indicated for each movement in the first part of this chapter.

75 See for the early historians of the Wahhābiyya, Peskes, Muhammad b. 'Abd al-Wahhā b; for Muhammad b. 'Abd al-Wahhāb's account of the sirra of the Prophet as an interpretation of his own religious and political programme, see Chapter 2 in this volume.

$7^{6}$ Bayly, “Age of Revolutions", 212ff. 
conduct in social affairs, government, and warfare, and for the overcoming of tribal and regional differences.

It was only in the emirate of 'Abd al-Qādir in Western Algeria and in the imamate in the Caucasus that the struggle against a European power was present from the beginning, whereas it gained in importance later in Eastern Algeria (Raḥmāniyya), in Libya and Chad (Sanūsiyya), Indonesia, and West Africa. It was postponed by Sayyid Ahmad to a later stage of his jihād in northern India, which began with his warfare against the Sikhs. In his final days, he apparently aimed at transforming his authority into a caliphate that would extend beyond northern India and cover Afghanistan and Central Asia. ${ }^{77}$

A khanate structure along stricter Islamic lines can be observed in Bukhārā under the Mangit ruler Shāh Murād. The establishment of a caliphate as an overarching structure of religious representation for the Muslims of the whole of Java was the aim of Dipanagara, the prince of Yogyakarta in Java, in his struggle against the Dutch (the so-called Java War, 1825-30). He can be documented as merging the local traditions and expectations of a future "just ruler" (ratu adil) with a caliphate model which combined the claim to succession of the Prophet with a perceived Ottoman model. ${ }^{78}$

In the case of the Arabian Najd, the emerging regime (since 1744) was a novel type of diarchy which rested on a mutual oath of allegiance (bay'a) between the Āl Su'ūd emirs of Diriyya and Muhammad b. 'Abd al-Wahhāb and his descendants as leading scholars of the new emirate, whose basic constitutional arrangement continues until the present in Saudi Arabia. The political and economic success of this polity in establishing a viable political and economic order in its region impressed the traveller J. L. Burckhardt who accompanied the Egyptian occupying forces. ${ }^{79}$ Some French revolutionaries, basing themselves on rather dim and indirect information, even compared the "Wahhābī religion" to their own official religious cult, the Théophilanthropie. ${ }^{80}$

The Caucasian imamate of Shāmil was built on a flexible governing structure, with the strong authority of the imam balanced by an increasing group

77 Gaborieau, Le Mahdi incompris, 197-218.

78 Carey, Prophecy, 152, 581, 612, 653, 666, 776, 855; Carey, Destiny, 6o, 221, 224. He even adopted the name of the Ottoman Sultan 'Abdülhamīd I for himself. It should be noted that, whereas the title "God's Caliph" (Kalifatullah) had already been part of the protocol of the rulers of Yogyakarta before, Dipanagara changed it into "Caliph of God's Prophet" (Kalifat Rasulullah), which highlights his attachment to the Prophet and his claim to represent his community.

79 See the description by Burckhardt, Notes, 2:95-133, 282-302, 361 . He labels their regime as "Muselmán puritanism and Bedouin government" (96).

8o Urvoy, "Le monde musulman", 42, quoting the French revolutionary politician Abbé Grégoire. 
of deputy leaders ( $n \bar{a} i b s)$ representing the different provinces and ethnic military units of the state. Shāmil himself first signed his letters and documents without any honorific title before turning to "Imam" or "Imam of the Faithful" (imām al-mu'mininn), until he finally adopted the caliphal title of "Commander of the Faithful" (amir al-mu'minin) after $1845 .{ }^{81}$ His strong political authority was defended by scholars supporting his rule against dissidents who criticised his arrogation of powers. ${ }^{82}$ As other Islamic movements of the time, he and his followers linked their eventful course to the life of the Prophet. For Shāmil himself, a great appreciation of his copy of Ḥalabī's Life of the Prophet (al-Sirra al-halabiyya) is attested. ${ }^{83}$

The tribal alliance founded by 'Abd al-Qādir's father, the Algerian Qādirī shaykh Muhyī l-Dīn, in the Mascara region in November $183^{2}$ for the organisation of armed resistance against the French also took on the form of a caliphate, with the proclamation of 'Abd al-Qādir as "Commander of the Faithful" (amìr al-mu'minin). After the first successes of his military campaigns, the title was recognised in the following year by the Desmichels Treaty, which he concluded with the French in February $1834 .{ }^{84}$ The principal coins that were established for the emerging polity were named muhammadiyya. The Sufi background of its leaders can be gleaned from their design of the officers' uniform jackets, where the name of the Prophet was written on the left side below the heart (with the name of God on the right side at the level of the breast). ${ }^{85}$

Similar novel solutions for the representation of different ethnic communities and regional groups and for the accommodation of scholarly and military interests can be identified in West Africa: this holds especially for Futa Jalon with its rotating imamate diarchy based on a system of provincial mosque centres, ${ }^{86}$ and for the Sokoto caliphate and its multi-ethnic emirates which were developed out of older city-state traditions. ${ }^{87}$ It included the Dīna caliphate in Masina with its large council of religious scholars that was advising

$81 \quad$ Kemper, Herrschaft, 278.

82 Kemper, Herrschaft, 392-401.

83 Kemper, Herrschaft, 282; for the Sira halabiyya and its significance, see the contribution of C. Mayeur-Jaouen to the first volume of this series.

84 Bouyerdene, Emir Abd El-Kader, 43, 51, 57.

85 For the muhammadiyya coin and the uniform jackets, see Bouyerdene, Emir Abd El-Kader, 57 .

86 Robinson, Holy War, $5^{2}$ ff. On the constitutional arrangement of the Futa Jalon imamate, and its crisis that was probably settled by the local scholar-poet Tierno Dadou Dalen in the 1840s, see Bohas et al., eds, Islam et bonne gouvernance, 21-113.

87 See for this especially Usman, ed., Studies; for the ethno-religious constitutional arrangement of the Ilorin emirate, see Reichmuth, "A Regional Centre"; Reichmuth, "A Sacred Community". 
the caliph, running the state, and supervising the local trade and agriculture including the grazing regime of the Fulbe cattle herders. ${ }^{88}$ Many of these newly formed political structures operated in highly literate communities that developed elaborate educational institutions, and they are well documented in local written sources as well as in the oral traditions of their regions. The multitude of newly established regional polities that claimed to be following Prophetic and early Islamic models remain a remarkable feature of the Muslim world during this period. It easily ties in with the struggles that went on for the reshaping of political theory, claim-making, and practice in Europe and America, and that equally included many references to ancient Greek and Roman republican as well as imperial models.

The Padri scholars of Minangkabau (Sumatra) declared to follow the sunna practice as witnessed by some of their returning pilgrims in 1803 (i.e. at the beginning of Wahhābī rule over the Hijāz). Although clinging to the celebration of the mawlid of the Prophet and to their own Sufi practice, they pursued a militant reformist line against the matrilineal communal authorities, against the common disruption of trade routes by highwaymen, and against alcohol and cockfight betting that were widespread at the local marketplaces. They successfully established an expanding network of settlements linked by safe trade routes and placed under the control of their $q \bar{a} d \bar{\imath}$ s and imams as guardians of the Prophetic sunna against customary legal practice (adat) and its local aristocratic proponents. Their power was based on their own militias that had been originally formed out of their student followers. Profiting from the expanding coffee trade they also lived off the wealth of their opposing neighbours and other enemies through plunder and enslavement. The ensuing civil war raged until the early 183 os when their most powerful leader, Imam Bonjol, formally abandoned that enmity against local adat customary practice and sought the cooperation with the old communal authorities in order to forge an alliance for a joint struggle against the growing Dutch competition and encroachment. This, too, was justified on religious grounds with the changed regime and religious practice that had taken place in the meantime in the Hijāz itself. ${ }^{89}$

\subsubsection{Eschatological Claims and Expectations}

Various claims of eschatological links with the Prophet are attested for the Islamic revolutionary movements of the period before and after 180o. The

88 Loimeier, Muslim Societies in Africa, $122 \mathrm{ff}$.

89 See for this Dobbin, Islamic Revivalism; Hadler, "Historiography of Violence"; Zakaria, "Landscapes and Conversions". 
meaning of the term "eschatology" is understood here as the expected fulfilment of the divine promise of salvation and reward for the believers at the end of times, and also its proleptic unfolding in the course of history. The latter could be realised for believers by direct vision of the Prophet or by his authentic representation through a religious or political leader as a "renewer" (mujaddid) of his message, culminating in the Mahdī, who is said to appear before the end of the world. The turn of the twelfth Islamic century (in the year $1200 / 1785$ ) in particular was ripe with eschatological expectations. ${ }^{90}$ Reported visions of the Prophet not infrequently came up in the context of Sufi life and practice, in the West African Qãdiriyya as well as in the Naqshbandiyya and other țuruq in the East. Shāh Walī Allāh already related a number of vocational visions experienced during his stay in the Haramayn (1731-32)..$^{91}$ In the case of Sīdī al-Mukhtār al-Kuntī, 'Uthmān b. Fōdiye in West Africa, and Sayyid Aḥmad Shahìd in northern India they became part of the leaders' own narrative of their divine call to leadership and struggle..$^{92}$ The founders of the Rahmanniyya and the Tijāniyya equally claimed visionary contact with the Prophet, the first receiving promises of salvation for his community from him, the second being assured of his status as "seal of the saints" (khatm al-awliy $\bar{a}^{3}$ ) and obtaining authorisation for his litanies (awräd) and for his way of Sufi training (tarbiya). ${ }^{93}$ By this immediate link of their founder to the Prophet, the Tijāniyya claimed spiritual superiority over all other Sufis.

The title of a mujaddid, a renewer of the religion of the Prophet who according to Prophetic tradition will appear at every turn of a new Islamic century, was claimed and much discussed at the beginning of the thirteenth Islamic century (1200/1785-86). Several scholars and Sufi leaders, like Shāh Walī Allāh and Sidī al-Mukhtār al-Kuntī, claimed this status for themselves, and it played an important role for 'Uthmān b. Fōdiye. ${ }^{94}$ In the ideology of the Sokoto caliphate this involved specific demands of religious allegiance from the local Islamic communities which formed part of this extended polity. The reformist emir Shāh Murād in Bukhārā was also presented as a mujaddid by his learned

$90 \quad$ See e.g. for Sokoto Al-Hajj, "Thirteenth Century".

91 Baljon, Religion and Thought, 6, 15-20, 130.

92 For Sīdī al-Mukhtār al-Kuntī, see Batran, Qadiriyyah Brotherhood, 88; for 'Uthmān b. Fōdiye, see Hiskett, Sword of Truth, 66; Brenner, "Concepts of Țariqa", 46; for Sayyid Ahmad Shahīd, see Gaborieau, Le Mahdi incompris, 64.

93 For Muhammad b. 'Abd al-Rahmān al-Azharī, see Rinn, Marabouts et Khwouan, 467; Margoliouth, "Raḥmāniyya", 399f.; Clancy Smith, Rebel and Saint, 39ff.; for Aḥmad al-Tijānī, see Abun-Nasr, "al-Tidjān̄̄”; Abun-Nasr, "Tidjāniyya”, with further references.

94 For Walī Allāh, see Baljon, Religion and Thought, 129ff.; for Sīdī al-Mukhtār, Batran, Qadiriyyah Brotherhood, 83-89; Brenner, "Concepts of Țariqa", 46; for 'Uthmān b. Fōdiye, see Last, Sokoto Caliphate, lxxxiff.; Brenner, "Concepts of Tarīqa", 49; "Fä’ida 'azìma". 
historiographers. ${ }^{95}$ The same epithet has been documented for the contemporary Ottoman reformist sultans Selīm III (1789-1807) and Maḥmūd II $(1809-39){ }^{96}$

The Mahdi title was equally brought up for these scholarly and political leaders. There was some hesitation on their part vis-à-vis this highly charged attribute. Ibn Fōdiye finally refused this role and described himself instead as a "fore-runner" of the Mahdī (Hausa barden Mahdi).${ }^{97}$ Mahdī pretenders who rose against the French around the middle of the nineteenth century were supported by the Rahmāniyya in Eastern Algeria. ${ }^{98}$

A rather specific oscillation between outright Mahdism and attenuated eschatological claims can be found for Sayyid Ahmad Shahīd in northern India. He was presented in his final years by his leading ideologist as a "Mahdī in-between" (Mahdī al-wasaț), who is said to appear after the end of the first half of the time left between the life of the Prophet and the final end of the world. ${ }^{99}$ But many of his adherents remained committed to a fully-fledged Mahdist expectation after the final battle of Balakōt (1831), when he is said to have disappeared without leaving any trace of his body.

Eschatological claims found an equally attentive audience in a period of political and cultural recovery in Qajar Iran in the mid-nineteenth century. ${ }^{100}$ In a climate of growing dissatisfaction with the hardening of the Qajar regime and the ușülì scholarly dominance, the young scholar and trader Sayyid 'Alī Muhammad (d. 1852) of Shīrāz gained considerable popularity with a radical challenge to the established patterns of political and religious leadership. He declared to be the sole "gateway" $(b \bar{a} b)$ to the Prophet and to the Mahdī, later claimed Mahdiship for himself, and finally proclaimed to be the initiator of a novel cycle of Prophecy. The year of his proclamation (126o/1844) was the thousandth anniversary of the beginning of the Twelfth Imam's occultation $(260 / 874)$. Although at first clinging to the validity of Muhammad's Prophetic mission, Sayyid 'Alī Muhammad finally announced the end of the rule of the sharîa and of the Islamic Prophetic cycle, and the beginning of a new era built on his own revealed book. Here, as in many of the other movements which we

95 von Kügelgen, Legitimierung, 303-17, 417ff., $459 \mathrm{ff}$.

96 For Selīm III and his Sufi poet and friend Shaykh Ghālib, see Holbrook, Unreadable Shores of Love; Yüksel, Şeyh Galip, 16. For Maḥmūd II, see the introduction of Shihāb al-Dīn Maḥmūd al-Ālūsī to his Qửānic commentary Rūḥ al-ma'ānī, 1:4. Adeleye, "Sifofin Shehu"; Skinner, Anthology, 132-36.

98 Clancy Smith, Rebel and Saint, 92-124, 168-213.

99 For the concept of the Mahdī al-wasat put forward for Sayyid Ahmmad Shahīd, see Gaborieau, Le Mahdi incompris, 222-31.

100 For an overview of this period, see Amanat, Iran, chapter 4, $179 \mathrm{ff}$. 
have mentioned, the dissatisfaction with the state of the Muslim community and its existing sociopolitical order is hard to assess for its range, but certainly can be sensed. In this spectacular case this was taken beyond the limits of Islam. ${ }^{101}$ The Bahāī offshoot of the Bābīs would later pursue its development towards a separate religion with even more resolve and success. ${ }^{102}$

\subsection{Conclusion}

We have attempted to offer an overview of religious and political developments in many Muslim regions in the late eighteenth and early nineteenth centuries that coincided with the European and American "Age of Revolutions" and that fully justify the historiographical extension of that label to the Muslim world. For the establishment of a richer comparative framework for this period, much still remains to be done. Some forms of attachment to the person of the Prophet Muhammad were highlighted that obviously played a crucial role for the movements presented here and that tie in with the rising significance of Prophetic piety in the course of the early modern period in the Muslim world. ${ }^{103}$ Here, too, much in-depth study of local and regional developments as well as a good deal of comparative research are still required.

The "Muslim Age of Revolutions", which was outlined here, had its internal dynamics which sprang from the same geopolitical and global economic conditions as its European and American counterparts. The decline of the large Eurasian Muslim empires, which went along in several regions with an irreversible decay of Islamic imperial authority, contributed to it as much as the increasingly entangled developments and crises of the global economy, and the growing networks of Muslim scholarly communication linking widely distant and even remote regions to the Holy Cities and to each other. The view from the more peripheral angles of the Muslim world which was chosen in this presentation perhaps brings this out with fuller clarity. Whether in the case of the Atlantic slave trade, which culminated in this period and included or affected important Muslim regions in West Africa, or of the European economic and military encroachment and competition in South and South East Asia that increased tremendously during the same time, Muslims were actively

101 See for the Bāb and for the development of his doctrine the references mentioned above (note 16).

102 See Cole, "Bahaism i. The Faith", and the other articles of the "Bahaism" cluster in the Encyclopaedia Iranica.

103 See for this already Reichmuth, "Aspects of Prophetic Piety"; Mayeur-Jaouen, "À la poursuite de la réforme'", $356 \mathrm{ff}$. 
as well as passively involved in these globalising developments. Struggling for an authentic Islamic authority built on recognised Prophetic standards, they were nevertheless closely bound to the specific political and cultural conditions of their respective regions. Their connections with the transnational "revolutionary culture" of European radicalism remained minimal in the period in question. ${ }^{104}$ At the same time, these movements often shaped and directed the reaction of the local Muslim population to European economic and political expansion. Their efforts built upon the Prophet and his sunna for political legitimation and statehood, for the social and ethical disciplining of the Muslim individual, and for Muslim public culture and regional and historical consciousness in general. With their critique of established Muslim religious and political practice, and their repeated claim of a return to the model of the Prophet and the early Muslim community, they created new political traditions and patterns of reference that have remained significant until the present. Their undeniable impact upon modern Muslim statehood is an equally important task of further research.

The eschatological colouring of the movements which were described here should not blind us to their remarkable attempts to find novel solutions to the political and cultural challenges which their societies were facing in this period. These went far beyond being trapped in cyclical historical and sociocultural patterns, such as those that were widely ascribed to Islam, even by Marx and Engels, but rather showed attempts to establish a workable balance of Islamic doctrines with local political and social norms. ${ }^{105}$ The special case of Bābism in Iran, with its fundamental critique of Islamic authority and with the establishment of a new religion, brings out the great sociocultural tensions and the crisis of religious and political legitimacy, which can be sensed with hindsight also in other parts of the Muslim world, in an age that was highly dynamic and indeed volatile for people in five continents.

\section{Acknowledgements}

I want to express my gratitude to Rachida Chih (Paris, London), Gudrun Krämer (Berlin), Hans Hinrich Biesterfeldt (Bochum), and Rainer Brunner (Freiburg) for their comments and critical enquiries on previous versions of this chapter.

\footnotetext{
104 For this transnational "revolutionary culture" of European radicalism, see the recent comparative study by Murray-Miller, Revolutionary Europe.

105 For Engels and his rather unfavourable comparison of Islam with early Christianity, see his "Zur Geschichte des Urchristentums", 472; Bousquet, "Marx et Engels se sont-ils intéressés aux questions islamiques?".
} 


\section{Bibliography}

\section{Primary Sources}

Adeleye, R. A. "Sifofin Shehu: An Autobiography and Character Study of Shehu 'Uthmān b. Fōdiye in Verse", Research Bulletin: Centre of Arabic Documentation 2/1 (1966), 1-36.

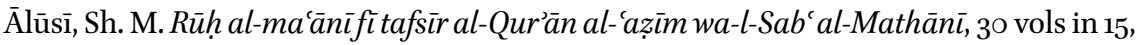
Beirut, Dār Iḥyā' al-Turāth al-'Arabī, 1970 [repr. Cairo, Idārat al-Ṭibā'a al-Munīriyya, 1934].

Chodkiewicz, M. Émir Abd el-Kader, Écrits spirituels, presentés et traduits de l'arabe, Paris, Le Seuil, 1982.

"Fä̀ida 'azìma", Research Bulletin: Centre of Arabic Documentation 18-19 (1990-91), $97 \mathrm{ff.}$

Gross, J. -A., and A. Urunbaev. "Introductory Essays", in A. Urunbaev, ed., The Letters of Khwāja Ubayd Allāh Ahrār, Leiden, Brill, 2002, 1-92.

Hermansen, M. K. The Conclusive Argument from God: Shāh Walı Allāh of Delhı̈s Hujjat Allāh al-Bāligha, Leiden, Brill, 1995.

Hermansen, M. K. Shah Wali Allah's Treatises on Islamic Law: Two Treatises on Islamic Law by Shah Wali Allah: al-Inșāf fī Bayān Sabab al-Ikhtilāf and 'Iqd al-Jīd fì Aḥkām al-Ijtihād wa-l-Taqlīd, Louisville, Fons Vitae, 2011.

Kattānī, 'A. H.̣. Fihris al-fahāris wa-l-athbāt wa-mu'jam al-ma'ājim wa-l-mashyakhāt wa-l-musalsalāt, 3 vols, ed. I. 'Abbās, Beirut, Dār al-Gharb al-Islāmī, 1982.

Radtke, B., J. O'Kane, K. S. Vikør, and R. S. O'Fahey, The Exoteric Ahmad Ibn Idrīs: A Sufi's Critique of the Madhāhib and the Wahhābis, Leiden, Brill, 2000.

Schefer, C. Histoire de l'Asie Centrale par Mir Aboul Kerim Boukhary - Afghanistan, Boukhara, Khiva, Khokand depuis les dernières années du règne de Nadir Chah, 1153 jusqu'en 1233 de l-hégire, 1740-1818 A. D., Amsterdam, Philo Press, 1970 [Paris, 1876].

Sow, A. I., ed. La femme, la vache, La foi. Écrivains \& poètes du Foûta-Djalon, Paris, Julliard, 1966.

Sow, A. I., ed. Chroniques et récits du Fouta Djallon, Paris, Klincksieck, 1968.

Sperl, S., and C. Shackle, eds. Qasida Poetry in Islamic Asia \& Africa, 2 vols, Leiden, Brill 1996.

'Uthmān b. Fōdiye. Bayān wujūb al-hijra 'ala l-ibād, ed. and trans. F. H. El Masri, Khartoum, Khartoum University Press, 1978.

van Ronkel, P. S. "Inlandsche getuigenissen aangaande den Padri-oorlog", De Indische Gids 37 (1915), 1099-1119, 1243-59.

Witkam, J. J. "Images of Mecca and Medina in Islamic Manuscripts: The Case of the Prayer Book of the Moroccan Activist and Mystic Muhammad b. Sulayman al-Jazuli (d. 1465) in Particular", PowerPoint presentation, Kuala Lumpur, International Islamic University of Malaysia (IIUM), 12 March 2012. Accessed 18 December 2019. www.yumpu.com/en/document/read/23543638/images-of-mecca-en-medina -in-islamic-manuscripts. 
Witkam, J. J. "Hajj Manuscripts from Southeast Asia”, PowerPoint presentation, "Hajj: Journey to the Heart of Islam", conference at the British Museum, London, 22-24 March 2012. Accessed 18 December 2019. www.islamicmanuscripts.info/files/ Hajj-manuscripts-from-Southeast-Asia-2012.pdf.

\section{Secondary Literature}

Abun-Nasr, J. M. The Tijaniyya: A Sufi Order in the Modern World, London, Oxford University Press, 1965 .

Abun-Nasr, J. M. “al-Tidjān̄̄", in P. Bearman et al., eds, Encyclopaedia of Islam, Second Edition, Leiden, Brill, 196o-2009, X, 463ff.

Abun-Nasr, J. M. "Tidjāniyya”, in P. Bearman et al., eds, Encyclopaedia of Islam, Second Edition, Leiden Brill, 1960-2009, X, $464 \mathrm{ff}$.

Abun-Nasr, J. M. A History of the Maghrib in the Islamic Period, Cambridge, Cambridge University Press, 1987.

Adeleye, R. A., and C. C. Stewart. "The Sokoto Caliphate in the Nineteenth Century", in J. F. Ade Ajayi and M. Crowder, eds, History of West Africa, vol. 2, 2nd ed., London, Longman, 1987, 86-131.

Ahmad, Q. The Wahhabi Movement in India, 2nd rev. ed., New Delhi, Manohar, 1994.

Ahmad Khan, M. D. History of the Fara'idi Movement in Bengal (1818-1906), Karachi, Pakistan Historical Society, 1965.

Ajayi, J. F. A., and M. Crowder, eds. History of West Africa, vol. 1, 3rd ed., London, Longman, 1985 .

Ajayi, J. F. A., and M. Crowder, eds. History of West Africa, vol. 2, 2nd ed., London, Longman, 1987 .

Amanat, A. Resurrection and Renewal: The Making of the Babi Movement in Iran, 18441850, Ithaca, Cornell University Press, 1989.

Amanat, A. Iran: A Modern History, New Haven, Yale University History, 2017.

Armitage, D., and S. Subrahmanyam, eds. The Age of Revolutions in Global Context, c. 1760-1840, Basingstoke, Palgrave-Macmillan, 2010.

Armitage, D., and S. Subrahmanyam. "Introduction", in D. Armitage and S. Subrahmanyam, eds, The Age of Revolutions in Global Context, c. 1760-1840, Basingstoke, Palgrave-Macmillan, 2010, xii-xxxii.

Aubin, F. "En Islam chinois: quels Naqshbandis?", in M. Gaborieau, A. Popovic, and T. Zarcone, eds, Naqshbandis. Cheminements et situation actuelle d'un ordre mystique musulman, Istanbul-Paris, Éditions Is Is, 1990, 491-572.

Axworthy, M. “The Army of Nader Shah", Iran Studies 4o/5 (2007), 635-46.

Baljon, J. M. S. Religion and Thought of Shāh Wal̄ Allāh Dihlawī, 1703-1762, Leiden, Brill, 1986.

Bâ, A. H., and J. Daget. L'empire peul du Macina. I (1818-1853), Koulouba, Institut Français d'Afrique Noire, Centre du Soudan, 1955. 
Batran, A. A. The Qadiriyya Brotherhood in West Africa and the Western Sahara: The Life and Times of Shaykh al-Mukhtar al-Kunti (1729-1811), Rabat, Publication de l'Institut des Etudes Africaines, 2001.

Batran, A. A. "The Kunta, Sīdī al-Mukhtār al-Kuntī, and the Office of Shaykh al-Tarīq al-Qadiriyya", in J. R. Willis, ed., Studies in West African History, vol. 1, London, Routledge, 1979, 113-47.

Bayly, C. A. The Birth of the Modern World, 1780-1914: Global Connections and Comparisons, Oxford, Blackwell, 2004.

Bayly, C. A. "The Age of Revolutions in Global Context: An Afterword", in D. Armitage and S. Subrahmanyam, eds, The Age of Revolutions in Global Context, c. 1760-1840, Basingstoke, Palgrave-Macmillan, 2010, 209-17.

Behrens, M. “Ein Garten des Paradieses”: Die Prophetenmoschee von Medina, Würzburg, Ergon, 2007.

Bennison, A. Jihad and Its Interpretations in Pre-colonial Morocco, London, Longman, 2002.

Bloch. R. H. Visionary Republic: Millennial Themes in American Thought, 1756-1800, Cambridge, Cambridge University Press, 1985.

Bohas, G., et al., eds. Islam et bonne gouvernance au XIX $X^{e}$ siècle dans les sources Arabes du Fouta-Djalon, Paris, Geuthner, 2018.

Boulègue, J., and J. Suret-Canale. "The Western Atlantic Coast”, in J. F. Ade Ajayi and M. Crowder, eds, History of West Africa, vol. 1, 3rd ed., London, Longman, 1985, 503-30.

Bousquet, G. -H. "Marx et Engels se sont-ils intéressés aux questions islamiques?", Studia Islamica 30 (1969), 119-30.

Bouyerdene, A. Emir Abd El-Kader: Hero and Saint of Islam, Bloomington, World Wisdom, 2012.

Bravmann, R. "A Fragment of Paradise", The Muslim World 78/1 (January 1988), 29-37.

Brenner, L. "Concepts of Tarīqa in West Africa: The Case of the Qādiriyya”, in D. Cruise O'Brien and C. Coulon, eds, Charisma and Brotherhood in African Islam, Oxford, Clarendon Press, 1988, 33-52.

Brown, S. J. "Movements of Christian Awakening in Revolutionary Europe, 17901815", in S. J. Brown and T. Tackett, eds, Cambridge History of Christianity, Volume 7: Enlightenment, Reawakening and Revolution, 1660-1815, Cambridge, Cambridge University Press, 2006, 575-95.

Brown, S. J., and T. Tackett, eds. Cambridge History of Christianity, Volume 7: Enlightenment, Reawakening and Revolution, 1660-1815, Cambridge, Cambridge University Press, 2006.

Brown, W. H. "The Caliphate of Hamdullahi, ca. 1816-1864: A Study in African History and Tradition", PhD diss., University of Wisconsin-Madison, 1968. 
Burckhardt, J. L. Notes on the Bedouins and Wahábys, 2 vols, London, Henry Colburn and Richard Bentley, 1831.

Caffiero, M. "Prophétie, millenium et révolution", Archives des sciences sociales des religions 66/2 (1988),187-99.

Carey, P. The Power of Prophecy: Prince Dipanagara and the End of the Old Order in Java, 1785-1855, 2nd ed., Leiden, KITLV Press, 2008.

Carey, P. Destiny: The Life of Prince Diponegoro of Yogyakarta, 1785-1855, Frankfurt, Peter Lang, 2014.

Chih, R. Sufism in Ottoman Egypt: Circulation, Renewal and Authority in the Seventeenth and Eighteenth Centuries, Abingdon, Routledge, 2019.

Chodkiewicz, M. An Ocean without Shore: Ibn 'Arabī, the Book, and the Law, Albany, State University of New York Press, 1993.

Clancy Smith, J. A. Rebel and Saint: Muslim Notables, Populist Protest, Colonial Encounters (Algeria and Tunisia, 1800-1904), Berkeley, University of California Press, 1994.

Cole, J. "Bahaism i. The Faith", Encyclopaedia Iranica. Last updated 23 August 2011. www.iranicaonline.org/articles/bahaism-i.

Currie, J. M. D. "Kadizadeli Ottoman Scholarship, Muḥammad ibn 'Abd al-Wahhāb, and the Rise of the Saudi State", Journal of Islamic Studies 26 (2015), 265-88.

Dallal, A. S. "The Origins and Early Development of Islamic Reform", in M. Cook, ed., The Cambridge History of Islam, Volume 6: Muslims and Modernity: Culture and Society since 1800, Cambridge, Cambridge University Press, 2011, 107-47.

Dallal, A. S. Islam without Europe: Traditions of Reform in Eighteenth-Century Islamic Thought, Chapel Hill, University of North Carolina Press, 2018.

Darwin, J. After Tamerlane: The Rise and Fall of Global Empire, London, Penguin Books, 2007.

Davidson, G. "Carrying on the Tradition: An Intellectual and Social History of Postcanonical Hadith Transmission", PhD diss. University of Chicago, 2014.

Desan, S. "The French Revolution and Religion, $1795^{-1815}$ ", in S. J. Brown and T. Tackett, eds, Cambridge History of Christianity, Volume 7: Enlightenment, Reawakening and Revolution, 1660-1815, Cambridge, Cambridge University Press, 2006, 556-74.

Diallo, T. Les institutions politiques du Fouta Dyalon au XIX ${ }^{e}$ siècle, Dakar, IFAN, 1972.

Dobbin, C. Islamic Revivalism in a Changing Peasant Economy: Central Sumatra, 17841847, London, Routledge, 2017 [1983].

Dutton, G. E., ed. Voices of Southeast Asia: Essential Readings from Antiquity to the Present, Armonk and London, M. E. Sharp, 2014.

El Mansour, M. Morocco in the Reign of Mawlay Sulayman, Wisbech, Middle East and North African Studies Press, 1990.

El-Rouayheb, K. Islamic Intellectual History in the Seventeenth Century: Scholarly Currents in the Ottoman Empire and the Maghreb, Cambridge, Cambridge University Press, 2015. 
Engels, F. "Zur Geschichte des Urchristentums”, in K. Marx and F. Engels, Werke, vol. 22, 3rd ed., Berlin, Dietz Verlag, 1972, 447-73; online 6 April 1999. Accessed 8 May 2021. www.mlwerke.de/me/me22/me22_447.htm.

Eschraghi, A. Frühe Šaiȟ̄- und Bābì-Theologie. Die Beweise für Muhammads besonderes Prophetentum (ar-Risāla fī Ițbāt an-Nubuwwa al-Ḩāșșa), Einleitung, Edition und Erläuterungen, Leiden, Brill, 2004.

Etienne, B. Abdelkader, isthme des isthmes, barzakh al-barāzikh. Paris, Hachette-Pluriel, 2012.

Fahmy, K. "The Era of Muhammad 'Ali Pasha, 1805-1848", in M. W. Daly, ed., Cambridge History of Egypt, Volume 2: Modern Egypt, from 1517 to the End of the 2oth Century, Cambridge, Cambridge University Press, 1998, 139-79.

Fletcher, J. F. "The Naqshbandiyya in Northwest China”, in B. F. Manz, ed., Studies on Chinese and Islamic Inner Asia, Aldershot, Variorum, 1995, no. XI.

Florida, N. K. Writing the Past, Inscribing the Future: Historiography as Prophecy in Colonial Java, Durham and London, Duke University Press, 1995.

Frank, A. J. Islamic Historiography and "Bulghar" Identity among the Tatars and Bashkirs of Russia, Leiden, Brill, 1998.

Futi, al-Hājj 'Umar. Voilá ce qui est arrivé. Bayan ma waqa'a d'al-Hagg 'Umar al-Futi, trans. and ed. S. M. Mahibou and J. -L. Triaud, Paris, CNRS, 1983.

Gaborieau, M. Le Mahdi incompris. Sayyid Ahmad Barelwî (1786-1831) et le millénarisme en Inde, Paris, CNRs Éditions, 2010.

Gammer, M. Muslim Resistance to the Tsar: Shamil and the Conquest of Chechnia and Daghestan, London, Franc Cass, 1994.

Hadler, J. "A Historiography of Violence and the Secular State of Indonesia: Tuanku Imam Bondjol and the Uses of History", The Journal of Asian Studies 67/3 (2008), 971-1010.

Al-Hajj, M. A. "The Thirteenth Century in Muslim Eschatology: Mahdist Expectations in the Sokoto Caliphate", Research Bulletin: Centre of Arabic Documentation 3/2 (1967), 100-15.

Hajjī, M. al-Zāwiya al-Dilāìyya wa-dawruhā al-dīn̄̄wa-l-'ilmī wa-l-siyāsī, 2nd ed., al-Dār al-Bayḍā', Maṭba'at al-Najāḥ al-Jadīda, 1988.

Harrak, F. "State and Religion in Eighteenth-Century Morocco: The Religious Policy of Sidi Muhammad b. Abd Allah", PhD diss., University of London, 1989.

Haykel, B. Revival and Reform in Islam: The Legacy of Muhammad al-Shawkani, Cambridge, Cambridge University Press, 2003.

Hiskett, M. The Sword of Truth: The Life and Times of the Shehu Usuman dan Fodio, Evanston, Northwestern University Press, 1994.

Hobsbawm, E. The Age of Revolution, 1789-1848, New York, Vintage Books, 1996 [1962]. Hochgeschwender, M. Amerikanische Religion. Evangelikalismus, Pfingstlertum, Fundamentalismus, Frankfurt, Verlag der Weltreligionen, 2007.

Hochgeschwender, M. Die Amerikanische Revolution, Munich, Beck, 2017. 
Holbrook, V. The Unreadable Shores of Love: Turkish Modernity and Mystical Romance, Austin, University of Texas Press, 1994.

Hunwick, J. O., comp. Arabic Literature of Africa, Volume 2: The Writings of Central Sudanic Africa, Leiden, Brill, 1995.

Ince, I. "Medina im 12./18. Jahrhundert: Politische Strukturen, Beziehungen und Konflikte, mit Einblicken in den Gelehrtendiskurs", PhD diss., Ruhr University Bochum, 2014. Accessed 21 February 2020. https://hss-opus.ub.ruhr-uni-bochum .de/opus4/frontdoor/index/index/year/2018/docId/4086.

Kemper, M. Sufis und Gelehrte in Tatarien und Baschkirien, 1789-1889. Der islamische Diskurs unter russischer Herrschaft, Berlin, Klaus Schwarz, 1998.

Kemper, M. "The Daghestani Legal Discourse on the Imamate", Central Asian Survey 21/3 (2002), 265-78.

Kemper, M. Herrschaft, Recht und Islam in Daghestan. Von den Khanaten und Gemeindebünden zum ğihäd-Staat, Wiesbaden, Reichert, 2005.

Knysh, A. Sufism: A New History of Islamic Mysticism, Princeton, Princeton University Press, 2017.

Lapidus, I. M. A History of Islamic Societies, 3rd ed., Cambridge, Cambridge University Press, 2014 [1st ed. 1989].

Last, M. The Sokoto Caliphate, London, Longman, 1977.

Last, M. "Reform in West Africa: The Jihäd Movements of the Nineteenth Century", in J. F. A. Ajayi and M. Crowder, eds, History of West Africa, vol. 2, 2nd ed., London, Longman, 1987, 1-47.

Lawson, T. Gnostic Apocalypse and Islam: Qur'an, Exegesis, Messianism, and the Literary Origins of the Babi Religion, London, Routledge, 2012.

Levtzion, N., and J. O. Voll, eds. Eighteenth-Century Renewal and Reform in Islam, Syracuse, Syracuse University Press, 1987.

Levtzion, N., and R. L. Pouwels, eds. The History of Islam in Africa, Athens, Ohio University Press, 2000.

Lipman, J. N. Familiar Strangers: A History of Muslims in Northwest China, Seattle and London, University of Washington Press, 1997.

Loimeier, R. Muslim Societies in Africa:A Historical Anthropology, Bloomington, Indiana University Press, 2013.

Longworth, P. "The Pugachev Revolt: The Last Great Cossack-Peasant Rising”, in H. A. Landsberger, ed., Rural Protest:Peasant Movements and Social Change, London, Macmillan, 1974, 194-256.

Lovejoy, P. E. Jihäd in West Africa during the Age of Revolutions, Athens, Ohio University Press, 2016.

MacEoin, D. M. The Messiah of Shiraz: Studies in Early and Middle Babism, Leiden, Brill, 2009. 
MacEoin, D. M. "Babism”, Encyclopaedia Iranica. Last updated 19 August 2011. www .iranicaonline.org/articles/babism.

Mack, B., andJ. Boyd. One Woman'sJihad:Nana Asma'u:Scholar and Scribe, Bloomington, Indiana University Press, 2000.

Margoliouth, D. S. "Raḥmāniyya", in C. E. Bosworth et al., eds, Encyclopaedia of Islam, Second Edition, Leiden Brill, 196o-2009, VIII, 399ff.

Marty, M. E. "The American Revolution and Religion, 1765-1815", in S. J. Brown and T. Tackett, eds, Cambridge History of Christianity, Volume 7: Enlightenment, Reawakening and Revolution, 1660-1815, Cambridge, Cambridge University Press, 2006, 497-516.

Mayeur-Jaouen, C. “À la poursuite de la réforme'. Renouveaux et debats historiographiques de l'histoire religieuse et intellectuelle de l'islam, $\mathrm{xv}^{\mathrm{e}}-\mathrm{xxl}^{\mathrm{e}}$ siècle", Archives. Histoire, Sciences Sociales 73/2 (2018), 317-58.

McDougall, J. "Abd al-Qādir, Amīr", in K. Fleet et al., eds, Encyclopaedia of Islam, Third Edition, Leiden, Brill, 2014, http://dx.doi.org/10.1163/1573-3912_ei3_COM_24657.

Moosa, E. 'Muwatța' Roundtable: Journey of the Muwatta' in Different Periods of the History of South Asia: Shāh Walīyullāh's Pursuit of Mālik", Islamic Law blog, 8 December 2019. Accessed 31 December 2019. https://bit.ly/3a8ufp.

Mouline, N. The Clerics of Islam: Religious Authority and Political Power in Saudi Arabia, New Haven, Yale University Press, 2014 [translated from the French version: Les clercs de l'Islam. Autorité religieuse et pouvoir politique en Arabie Saoudite, XVIII $X X I^{e}$ siècles, Paris, Presses universitaires, 2011].

Murray-Miller, G. Revolutionary Europe: Politics, Community and Culture in Transnational Context, 1775-1922, London, Bloomsbury, 2020.

Nafi, B. "A Teacher of Ibn 'Abd al-Wahhāb: Muḥammad Ḥayāt al-Sindī and the Revival of Aṣhāb al-Hadīth's Methodology", Islamic Law and Society 13/2 (2006), 208-41.

Al-Nagar, U. "The Asānīd of Shehu dan Fodio: How Far Are They a Contribution to His Biography?", Bulletin of Information: Fontes Historiae Africanae 9-10 (1984-85), 25-34.

Neumann, C. "Political and Diplomatic Developments", in S. Faroqhi, ed., Cambridge History of Turkey, Volume 3: The Later Ottoman Empire, Cambridge, Cambridge University Press, 2006, 44-62.

O'Fahey, R. S., comp. Arabic Literature of Africa, Volume 1: The Writings of Eastern Sudanic Africa to c. 1900, Leiden, Brill, 1994.

Oloruntimehin, B. O. The Segou Tukolor Empire, London, Humanities Press, 1972.

Ouzouf, M. La Fête révolutionnaire: 1789-1799, Paris, Gallimard, 1976.

Person, Y. "The Atlantic Coast and the Southern Savannas, 180o-188o", in J. F. A. Ajayi and M. Crowder, eds, History of West Africa, vol. 2, 2nd ed., London, Longman, 1987, $25^{\circ}-300$. 
Peskes, E. "Wahhābiyya 1. The 18th and 19th Centuries", in P. Bearman et al., eds, Encyclopaedia of Islam, Second Edition, Leiden, Brill, 196o-2009, XI, 39-45.

Peskes, E. Muhammad b. 'Abd al-Wahhāb (1703-1792) im Widerstreit. Untersuchungen zur Rekonstruktion der Frühgeschichte der Wahhābīya, Beirut, Franz Steiner, 1993.

Peskes, E. "The Wahhābiyya and Sufism in the Eighteenth Century", in F. de Jong and B. Radtke, eds, Islamic Mysticism Contested: Thirteen Centuries of Controversies and Polemics, Leiden, Brill, 1999, 145-61.

Peskes, E., ed. Wahhabism: Doctrine and Development, 2 vols, Berlin, Gerlach, 2016.

Peters, D. Politische und gesellschaftliche Vorstellungen in der Aufstandsbewegung unter Pugachev, 1773-1775, Wiesbaden, Harrassowitz, 1973.

Pink, J. "Where Does Modernity Begin? Muhammad al-Shawkānī and the Tradition of Tafsīr", in A. Görke and J. Pink, eds, Tafsīr and Islamic Intellectual History: Explorations of a Genre, Oxford, Oxford University Press, 2014, 323-6o.

Rebstock, U. Maurische Literaturgeschichte, 3 vols, Würzburg, Ergon, 2001.

Reese, S., ed. The Transmission of Learning in Islamic Africa, Leiden, Brill, 2004.

Reichmuth, S. "A Sacred Community: Scholars, Saints, and Emirs in a Prayer Text from Ilorin", Sudanic Africa 6 (1995), 35-54.

Reichmuth, S. "A Regional Centre of Islamic Learning in Nigeria: Ilọrin and Its Influence on Yoruba Islam", in N. Grandin and M. Gaborieau, eds, Madrasa. La Transmission du savoir dans le Monde Musulman, Paris, éditions ARGUMENTS, 1997, 229-45.

Reichmuth, S. Islamische Bildung und soziale Integration in Ilorin (Nigeria) seit ca. 180o, Münster, LIT, 1998.

Reichmuth, S. "Murtaḍā az-Zabīdī (d. 1791) in Biographical and Autobiographical Accounts: Glimpses on Islamic Scholarship in the 18th Century", Die Welt des Islams 39/1 (1999), 64-102.

Reichmuth, S. "Murtaḍā al-Zabīdī (1732-1791) and the Africans: Islamic Discourse and Scholarly Networks in the Late Eighteenth Century", in S. Reese, ed., The Transmission of Learning in Islamic Africa, Leiden, Brill, 2004, 121-53.

Reichmuth, S. The World of Murtaḍā al-Zabìd̄̄ (1732-1791): Life, Networks and Writings, Oxford, Oxbow Books for the E. J. W. Gibb Memorial Trust, 2009.

Reichmuth, S. "Literary Culture and Arabic Manuscripts in 19th-Century Ilọin", in G. Krätli and G. Lydon, eds, The Trans-Saharan Book Trade: Manuscript Culture, Arabic Literacy and Intellectual History in Muslim Africa, Leiden, Brill 2011, 213-39.

Reichmuth, S. "The Quest for Sufi Transmissions as Links to the Prophet: Murtadā al-Zabīdī (d. 1791) and His Encyclopedic Collections of Sufi Salāsil", in I. Weinrich, ed., Performing Religion: Actors, Contexts, and Texts: Case Studies on Islam, Beirut, Ergon-Verlag, 2016, 75-99.

Reichmuth, S. "Aspects of Prophetic Piety in the Early Modern Period", Archives de sciences sociales des religions, $62^{\mathrm{e}}$ année, 178 (July-September 2017), 129-50. 
Rentz, G. The Birth of the Islamic Reform Movement in Saudi Arabia: Muhammad Ibn Abd Al-Wahhāb (1703/4-1792) and the Beginnings of Unitarian Empire in Arabia, London, Arabian Publishing, 2004.

Rinn, L. Marabouts et Khouan. Étude sur l'Islam en Algerie, Alger, Adolphe Jourdan, 1884.

Rizvi, S. A. A. Shāh Walī-Allāh and His Times, Canberra, Ma'rifat Publishing House, 198o.

Rizvi, S. A. A. Shâh 'Abd al-'Azîz: Puritanism, Sectarianism, Polemics and Jihâd, Canberra, Ma'rifat Publishing House, 1982.

Robinson, D. Chiefs and Clerics: Abdol Bokar Kan and Futa Toro, 1853-1891, Oxford, Clarendon Press, 1975.

Robinson, D. The Holy War of Umar Tal: The Western Sudan in the Mid-nineteenth Century, Oxford, Clarendon Press, 1985.

Robinson, D. "Revolutions in the Western Sudan", in N. Levtzion and R. L. Pouwels, eds, The History of Islam in Africa, Athens, Ohio University Press, 2000, 131-52.

Sanankoua, B. Un empire peul au XIXème siècle: La Dïna du Maasina, Paris, Karthala, 1990.

Schlobach, J. "Fortschritt oder Erlösung. Zu aufklärerischen und millenaristischen Begründungen der Revolution", Archiv für Kulturgeschichte 72 (1990), 202-2O.

Sedgwick, M. Saints and Sons: The Making and Remaking of the Rāshidi Ahmadi Sufi Order, 1799-2000, Leiden, Brill, 2005.

Seydou, C. "Poésie religieuse et inspiration populaire chez les Peul du Foûta Djalon", Journal of African Cultural Studies 14/1 (2001), 23-47.

Sidorko, C. Dschihad im Kaukasus. Antikolonialer Widerstand der Daghestaner und Tschetschenen gegen das Zarenreich (18. Jahrhundert bis 1859), Wiesbaden, Reichert, 2007 .

Skinner, N. An Anthology of Hausa Literature in Translation, Zaria, Northern Nigeria Publishing Co., 1980.

Sobieroj, F. "The Chinese Sufi Wiqāyatullāh Ma Mingxin and the Construction of His Sanctity in Kitāb al-Jahrī”, Asiatische Studien 70/1 (2016), 133-69.

Sobieroj, F. Variance in Arabic Manuscripts: Arabic Didactic Poems from the Eleventh to the Seventeenth Centuries - Analysis of Textual Variance and Its Control in the Manuscripts, Berlin, De Gruyter, 2016.

Sobieroj, F. "Spiritual Practice in the Arabic Hagiography of the Chinese Ğahrīya Sufi Order", Zeitschrift der Deutschen Morgenländischen Gesellschaft 169/1 (2019), 155-81. Starobinski, J. 1789: Les emblèmes de la raison, Paris, Flammarion, 1979.

Strube, J. Sozialismus, Katholizismus und Okkultismus im Frankreich des 19. Jahrhunderts, Berlin, De Gruyter, 2016.

Suryadi, S. "Shaikh Daud of Sunur: Conflict between Reformists and the Shațâriyyah Ŝufî Order in Rantau Pariaman in the First Half of the Nineteenth Century", Studia Islamica 8/3 (2001), 57-124. 
Tackett, T. "The French Revolution and Religion to 1794", in S. J. Brown and T. Tackett, eds, Cambridge History of Christianity, Volume 7: Enlightenment, Reawakening and Revolution, 1660-1815, Cambridge, Cambridge University Press, 2006, 536-55.

Travers, R. "Imperial Revolutions and Global Repercussions: South Asia and the World, c. $175^{\circ}-1850^{\circ}$ ", in D. Armitage and S. Subrahmanyam, eds, The Age of Revolutions in Global Context, c. 1760-1840, Basingstoke, Palgrave-Macmillan, 144-66.

Triaud, J. -L. "al-Sanūsī, Muḥammad b. 'Alī”, in C. E. Bosworth et al., eds, Encyclopaedia of Islam, Second Edition, Leiden, Brill, 196o-2009, IX, 22ff.

Triaud, J. -L. "Sanūsiyya", in C. E. Bosworth et al., eds, Encyclopaedia of Islam, Second Edition, Leiden, Brill, 196o-2009, IX, 24ff.

Urvoy, D. "Le monde musulman selon les idéaux de la Révolution française", Revue du monde musulman et de la Méditeranée 52-53 (1989), 35-48.

Usman, Y. B., ed. Studies in the History of the Sokoto Caliphate: The Sokoto Seminar Papers, Lagos, Third Press International, 1979.

Vikør, K. S. "The Sanūsiyya Tradition", in R. S. O'Fahey, comp., Arabic Literature of Africa, Volume 1: The Writings of Eastern Sudanic Africa to c. 19oo, Leiden, Brill, 1994, 166-77.

Vikør, K. S. Sufi and Scholar on the Desert Edge: Muhammad b. 'Alī al-Sanūsī and His Brotherhood, London, Hurst, 1995.

Vikør, K. S. "Sources for Sanūsī Studies", in Sudanic Africa: Texts and Sources 1, Bergen, Center for Middle Eastern and Islamic Studies, 1996.

Voll, J. O. "Muḥammad Ḥayyā al-Sindī and Muhammad ibn 'Abd al-Wahhāb: An Analysis of an Intellectual Group in Eighteenth-Century Medina", Bulletin of the School of Oriental and African Studies 38 (1975), 32-39.

Voll, J. O. "Abdallah ibn Salim al-Basri and 18th-Century Hadith Scholarship", Die Welt des Islams 42 (2002), 356-72.

von Kügelgen, A. Die Legitimierung der mittel-asiatischen Mangitendynastie, Istanbul, Ergon, 2002.

Vovelle, M. La mentalité révolutionnaire. Société et mentalités sous la Révolution française, Paris, Messidor/Éditions sociales, 1985.

Ward, W. R. "Evangelical Awakenings in the North-Atlantic World", in S. J. Brown and T. Tackett, eds, Cambridge History of Christianity, Volume 7: Enlightenment, Reawakening and Revolution, 1660-1815, Cambridge, Cambridge University Press, 2006, 329-47.

Ware, R. T. The Walking Qur'an: Islamic Education, Embodied Knowledge, and History in West Africa, Chapel Hill, University of North Carolina Press, 2014.

Wieringa, E. P. Catalogue of Malay and Minangkabau Manuscripts, vol. 1, Leiden, Legatum Warnerianum, 1998.

Wieringa, E. P. "A Tale of Two Cities and Two Modes of Reading: A Transformation of the Intended Function of the Syar Makah Dan Madinah", Die Welt des Islams 42/2 (2002), 174-206. 
Willis, J. R. "The Western Sudan from the Moroccan Invasion (1591) to the Death of al-Mukhtar al-Kunti (1811)", in J. F. A. Ajayi and M. Crowther, eds, History of West Africa, vol. 1, 3rd ed., London, Longman, 1985, 531-76.

Witkam, J. J. Vroomheid en activisme in een Islamitisch gebeedenboek. De geschiedenis van de Dalā̉il al-Khayrāt van al-Ğazūlī, Leiden, Universiteetsbibliotheek [Legatum Warnerianum], 2002.

Witkam, J. J. Inventory of the Oriental Manuscripts of the Library of the University of Leiden, Volume 2: Manuscripts Or. 1001 - Or. 2000, Leiden, Ter Lugt Press, 2007.

Yüksel, S. Şeyh Galip. Eserlerinin dil ve sanat değeri, Ankara, Ankara Üniversitesi Basımevi, 1963 .

Zakaria, F. "Landscapes and Conversions during the Padri Wars in Sumatra (1803-1840)" [abbreviated version of a chapter from "Sacred Ecologies of the North Sumatran Highlands: An Environmental History of Conversions", PhD diss., Yale University, 2017]. Accessed 30 November 2019. https://bit.ly/3wDZ7lg. 